\title{
Uwagi o Księdze aniołów Francesca Eiximenisa
}

\section{Abstract \\ Notes on Francesc Eiximenis' Book of Angels}

Francesc Eiximenis, a Catalan Franciscan and writer who lived in the 14th century, is not very well known today outside the narrow circle of Catalan researchers of the Middle Ages, even though he was a very popular author at the time and was eagerly translated into other languages. He was most enthusiastic about using his native language, i.e. Catalan, in which he wrote treatises on the truths of faith, theological questions, and social and political issues. The purpose of this study is to introduce Eiximenis and to present a Polish translation of an excerpt from the first book of his angelological treatise entitled Llibre dels àngels (Book of Angels). Rozalia Sasor's translation, together with an initial critical commentary on the text, is the first contemporary edition of this part of the treatise.

The paper, which is at the same time an introduction to the translation, is divided into four sections. In the first one, Sasor briefly discusses the state of knowledge about Francesc Eiximenis in Poland; in the second one, she presents his biography with a special emphasis on the time of his studies and his theological and philosophical interests, and in the third she characterises the Llibre del angels and the circumstances surrounding the creation of the work. It is worth noting at this point that the aforementioned characteristics focus on the properties of the language of the original, which contributed to the success of Llibre dels àngels among readers; it also takes up the previously undiscussed problem of the sources of the treatise. The paper ends with a comment on the Polish translation, in which Sasor explains how she prepared the source text for translation as there is no contemporary critical edition of the first three books of Llibre dels àngels; she also discusses the translation strategy she adopted. The whole publication is completed by a translation of selected excerpts from the first part of Llibre dels àngels, i.e. chapters 1-7, 9, 14, and 16-17, with critical commentary.

\section{TERMINUS}

t. $22(2020)$

z. 3 (56)

s. $251-284$

www.ejournals.eu/

Terminus

\section{Keywords}

Book of Angels,

Llibre dels

àngels, Francesc

Eiximenis,

Catalan literature, angelology 
Francesc Eiximenis, czternastowieczny kataloński franciszkanin i encyklopedysta, jest postacią właściwie nieznaną współczesnej polskiej nauce. Z jego bogatą twórczością powstającą w językach katalońskim i łacińskim badacze mogli się zapoznać jedynie pośrednio, przez opracowania na temat koncepcji średniowiecznego miasta ${ }^{\mathbf{1}}$, gastronomii historycznej ${ }^{2}$ oraz sztuki kaznodziejskiej ${ }^{3}$. Celem niniejszego artykułu jest uzupełnienie tej luki i przedstawienie Eiximenisa jako teologa i pisarza popularyzującego często bardzo złożone kwestie dotyczące wiary. Ponadto towarzyszące niniejszemu komentarzowi fragmenty Księgi aniołów ${ }^{4}$ stanowią zapowiedź i swego rodzaju wprowadzenie do powstającego właśnie przekładu Llibre dels àngels, który ukaże się w 2021 roku nakładem wydawnictwa Instytutu Studiów Franciszkańskich w Krakowie i będzie nie tylko pierwszym polskim tłumaczeniem wspomnianego traktatu, ale również pierwszym dziełem franciszkanina w całości dostępnym polskiemu czytelnikowi.

1 Do najważniejszych należą artykuły Natalii Bursiewicz, Teoria miasta idealnego Francisca Eiximenisa, „Quart” 1 (2013), nr 27, s. 3-18, oraz Rafała Hryszko, Sacrum w późnośredniowiecznej koncepcji miasta idealnego Francesca Eiximenisa, w: Sacrum w mieście. Średniowiecze i wczesna epoka nowożytna: wymiar religijny, kulturalny i społeczny, red. D. Quirini-Popławska, Ł. Burkiewicz, Kraków 2016, s. 39-53. Przy czym w pierwszym z wymienionych tekstów autorka dopuszcza się anachronizmu, posługując się kastylijską grafią imienia franciszkanina (Franscisco) i traktując jego twórczość jako przykład „[analizy] sytuacji politycznej i ekonomicznej ówczesnej Hiszpanii”, co nie odpowiada rzeczywistości politycznej tamtych czasów, ponieważ Korona Aragonii i Królestwo Kastylii nie stanowiły wówczas jednego organizmu państwowego. Przyjęta perspektywa badawcza powiela zapewne spojrzenie hiszpańskich opracowań tematu, z których korzystała autorka. Niemniej jednak jest to opracowanie wartościowe podobnie jak drugi z wymienionych tekstów. Wzmianki dotyczące koncepcji urbanistycznych Francesca Eiximenisa zawierają również monografie Zbigniewa Paszkowskiego, Historia idei miasta. Od antyku do renesansu, Szczecin 2015, s. 180-181, oraz Jarosława Szewczyka, Rozważania o domu, Białystok 2018, s. 120-122, a także artykuł Jerzego Łopata OFMConv, Wkład franciszkanów z XIII i XIV w. w rozwój teorii ekonomicznych (zarys problematyki), „Lignum Vitae. Rocznik teologiczny" 17 (2016), s. 107-108.

2 W monografii Rafała Hryszki i Rozalii Sasor, Średniowieczne słodycze katalońskie w źródłach o literaturze (z wyborem tekstów z XIV i V wieku), Kraków 2017, s. 217-247. Tam też jedyny większy fragment twórczości Eiximenisa tłumaczony na język polski, to jest rozdział 354 Terç del Crestià (Trzeciej księgi Chrześcijanina) zatytułowany „Jak dobrze używać picia i jedzenia”.

3 W polskich opracowaniach dotyczących ars praedicandi Eiximenis bywa wspominany jako autor traktatu o sztuce kaznodziejskiej, znanego w Polsce przynajmniej w jednym rękopisie z kodeksu spisanego przez Jakuba z Lipowej Góry (przed 1445 r.). Kodeks przechowywany w Bibliotece Jagiellońskiej (sygn. 471, f. 235v.-246r.) zawiera między innymi Ars praedicandi populo Eiximenisa z około 1383 roku. T. Michałowska, Średniowieczna teoria literatury w Polsce. Rekonesans, Wrocław 2007, s. 207.

4 Wybrane fragmenty przekładu pierwszej części Księgi aniołów Francesca Eiximenisa obejmują rozdziały I-VII, IX, XIV oraz XVI-XVII. 


\section{Francesc Eiximenis: duchowny i polityk}

Miejsce urodzenia Francesca Eiximenisa znamy z autobiograficznej wzmianki z pierwszej części zaplanowanej na dwanaście tomów i nigdy nieukończonej sumy zatytułowanej Lo Crestià (Chrześcijanin), w której czytamy: „powiadam, że autorem tej księgi, zaraz po Bogu, jest duchowny należący do Zakonu Braci Mniejszych, zwany bratem Franciszkiem Eiximenisem, pochodzący z miasta Girona”5 . Informacja o katalońskich korzeniach autora znajduje potwierdzenie również w wielkiej, ośmiotomowej kronice zgromadzenia franciszkanów Annales Minorum autorstwa Luke’a Waddinga, który dodatkowo podkreśla, że rodzinnych stron związanego z Walencją zakonnika należy szukać właśnie w Gironie: „Franciscus Ximenius, alter Gerundensis, Catalanus, non Valentianus"6. Te dwa potwierdzające się wzajemnie komentarze stanowią jedyny pewnik odnośnie do najwcześniejszych lat życia Eiximenisa, ponieważ nawet datę jego urodzin możemy ustalić zaledwie w przybliżeniu na lata 1327-1330, wyliczając ją od momentu przyjęcia święceń kapłańskich 22 grudnia 1352 roku w parafii Santa Maria de Sants w Barcelonie ${ }^{7}$. Dużo lepiej znany jest natomiast przebieg edukacji młodego franciszkanina, którą rozpoczął w prowadzonej przez braci mniejszych szkole, najprawdopodobniej w Gironie, a następnie kontynuował w Paryżu (w $1364 \mathrm{r}^{8}$ ), Awinionie (w 1365 roku przebywał na dworze papieża Urbana V) ${ }^{9}$, Oksfordzie, gdzie jednym z jego mistrzów był benedyktyn Uthred of Boldon ${ }^{\mathbf{1 0}}$, Kolonii, Florencji, Rzymie oraz Tuluzie. Tam też, w 1374 roku, uzyskał stopień mistrza teologii (licentia ubique docendi) ${ }^{\mathbf{1 1}}$ dzięki wsparciu panującego w Koronie Aragonii Piotra III (IV) Ceremonialnego ${ }^{\mathbf{1 2}}$ i jego żony Eleonory Sycylijskiej ${ }^{13}$. Warto być może nadmienić, że o ile pomoc królowej miała charakter

5 F. Eiximenis, Lo Crestià (selecció), a cura d'A. Hauf, Barcelona 1983, s. 36. Kat. „dic que l'actor d'aquest llibre és estat, aprés Déu, un religiós de l’orde dels Frares Menors, apellat frare Francesc Eximenes, natural de la ciutat de Gerona”. Wszystkie przekłady, jeśli nie podano inaczej, w tłumaczeniu własnym.

$6 \quad$ A. Hauf, D'Eiximenis a sor Isabel de Villena, Barcelona-València 1990, s. 60.

$7 \quad$ Francesc Eiximenis i la Casa Reial. Diplomatari 1373-1409, a cura de J. Riera i Sans, J. Torró i Torrent, Girona 2010, s. X-XI.

8 P. Vila, El viatge d'estudis de Francesc Eiximenis a París, „Quaderns de la Selva” 13 (2001), s. 266.

9 Ibidem.

10 A. Hauf, D'Eiximenis..., s. 63; D.J. Viera, Uthred of Boldon, O.S.B., Professor of Francesc Eiximenis, O.F.M., „Studia Monastica” 45 (2003), nùm. 1, s. 53-60.

11 Uniwersytet w Tuluzie był czwartym, po uczelniach Paryża, Oxfordu i Cambridge, uniwersytetem z uprawnieniami do przyznawania stopnia mistrza teologii, choć dopiero od 1360 roku, por. H. Rashdall, The Universities of Europe in the Middle Ages, vol. 2, part 1, Cambridge 2010 (reprint wyd. z 1895), s. $163-164$.

12 Podwójna numeracja władców Korony Aragonii łączy dwie szkoły historyczne: katalońską, która rozpoczyna numerację od unii personalnej Hrabstwa Barcelony z Królestwem Aragonii (tj. od 1137 r.), oraz hiszpańską, prowadzącą numerację ciągłą, obejmującą obydwa państwa.

13 O stopień mistrza teologii Eiximenis starał się, aby objąć katedrę teologii w studium provinciale zakonu w Lleidzie, do czego jednak nigdy nie doszło. Korespondencję związaną ze studiami Eiximenisa 
materialny, o tyle kataloński władca, zadowolony ze służby franciszkanina i wiążący z jego osobą jakieś bliżej nam nieznane plany ${ }^{\mathbf{1 4}}$, zwrócił się do księcia d’Anjou oraz hrabiego d'Armagnac ${ }^{15}$ wprost $\mathrm{z}$ prośbą o pomoc w wystaraniu się u kanclerza uniwersytetu o jak najszybsze przyznanie Eiximenisowi stopnia naukowego ${ }^{\mathbf{1 6}}$. W tej samej sprawie do kanclerza tuluzańskiej uczelni zwracała się dwukrotnie również Mata d'Armagnac, żona infanta Jana, argumentując, że obecność Eiximenisa na dworze księcia Girony jest niezbędna i nie może on zbyt wiele czasu poświęcić na studia ${ }^{17}$.

Ośrodkiem naukowym, który odcisnął największe piętno na osobowości twórczej Eiximenisa, był Uniwersytet Oksfordzki, a zwłaszcza studium franciszkańskie kontynuujące tradycje filozoficzno-teologiczne zapoczątkowane jeszcze w XIII wieku przez tak wybitne umysłowości jak Robert Grosseteste czy Roger Bacon. Wpływ angielskiej uczelni wyraźnie odzwierciedla przeprowadzony po śmierci Eiximenisa spis inwentarzowy jego biblioteki, zawierający liczne dzieła autorów w ten czy inny sposób związanych z Oksfordem: przede wszystkim Williama Ockhama i ockhamistów (takich jak Adam z Wodeham czy Jan z Dumbleton), a następnie Adelarda $\mathrm{z}$ Bath $^{\mathbf{1 8}}$, Aleksandra $z$ Hales ${ }^{19}$, Dunsa Szkota oraz jego uczniów, a także Jana z Walii ${ }^{20}$, logików Johannesa Venatora (Johna Huntmana) i Richarda Kilvingtona ${ }^{21}$ czy astrologa i tłumacza Awerroesa Michała Szkota ${ }^{22}$ oraz wielu innych ${ }^{23}$. Nie przypadkiem też na pierwszym miejscu listy wymieniam Ockhama, enfant terrible franciszkańskiej szkoły teologicznej, ponieważ Eiximenis należał do jego niejawnych zwolenników,

w Tuluzie opublikował Antoni Rubió i Lluch, Documents per l'Història de la Cultura Catalana Mig-eval, Barcelona 1908, s. 248-249.

14 „l'hajam gran mester per alguns afers nostres” (Wielce jest nam potrzebny w związku z naszymi sprawami), ibidem, s. 244.

15 List datowany na 1 września 1373 roku, wysłany z Barcelony (ibidem, s. 249, dokument nr CCLXIII). Jean II le Bossu, hrabia d’Armagnac, był bratem Maty d’Armagnac, żony księcia Girony, infanta Jana, przyszłego króla Jana I Myśliwego.

16 Ibidem, s. 244-245, 249.

17 Ibidem, s. 254-255; A. Hauf, D’Eiximenis..., s. 66-67.

18 Adelard z Bath (ok. 1080-ok. 1152) - filozof i tłumacz; przełożył na łacinę z greki i arabskiego liczne traktaty na temat astrologii, astronomii, matematyki i nauk przyrodniczych; jako jeden z pierwszych europejskich naukowców stosował w zapisie liczby arabskie. Uważa się, że jego prace znacząco wpłynęły na twórczość Roberta Grosseteste’a i Rogera Bacona.

19 Aleksander z Hales (ok. 1185-1245) - jeden z pierwszych zachodnich komentatorów Arystotelesa i autor pierwszego dużego komentarza do Sentencji Piotra Lombarda, ostro krytykowanego później przez Rogera Bacona. Najbardziej znany jako autor pierwszej sumy teologicznej, Summa universae theologiae, zwanej też Summa fratris Alexandrii.

20 Jan z Walii (?-ok. 1285) - teolog, znawca autorów klasycznych, których chętnie cytował we własnych traktatach; uznawany za prekursora myśli humanistycznej.

21 Richard Kilvington (ok. 1302-1361) - logik i filozof, współtwórca tak zwanej szkoły oksfordzkich kalkulatorów, która wprowadziła do scholastyki metody matematyczne.

22 Michał Szkot (1175-ok. 1232) - związany z sycylijskim dworem Ferdynanda II; poza Awerroesem tłumaczył pisma Arystotelesa oraz filozofów arabskich.

23 Pełny spis inwentarza post obitum podaje Jacques Monfrin, La Bibliothèque de Francesc Eiximenis (1409), „Studia Bibliographica” 22 (1991), s. 241-287. 
o czym świadczą aluzje i przytaczane bez podania źródła tezy, rozrzucone po wszystkich pismach katalońskiego autora ${ }^{24}$. Tezy ockhamistów wzbudzały kontrowersje jeszcze w drugiej połowie XIV wieku, nie dziwi więc ostrożność, z jaką Eiximenis dzielił się swoimi fascynacjami, poza tym miał już własny plan na życie, któremu zaangażowanie w debaty filozoficzno-teologiczne mogło zagrozić - zmierzał w stronę wielkiej polityki.

Po powrocie do kraju Eiximenis przebywał w zgromadzeniach franciszkańskich kolejno w Barcelonie, Vic (od 1379 r.) i Walencji (od 1381 r.), gdzie zajmował się nauczaniem teologii, działalnością pisarską oraz polityczną. Wiadomo, że już w latach siedemdziesiątych XIV wieku realizował misje dyplomatyczne dla króla Piotra Ceremonialnego, a po śmierci władcy dla jego synów Jana I Myśliwego i Marcina I Ludzkiego. Współpracował również z radnymi Barcelony i Walencji, aktywnie uczestnicząc w życiu politycznym obydwu ośrodków miejskich, a także z królową Marią de Luna, żoną Marcina I Ludzkiego ${ }^{25}$. O rozległych kontaktach Eiximenisa świadczą choćby dedykacje jego dzieł skierowane do tak ważnych osobistości, jak Alfons IV Starszy (markiz de Villena, hrabia Ribagorçy i Dènii oraz książę Gandii, adresat Dotzè del Crestià), członkowie rady miasta Walencji (Regiment de la cosa pública), Pere d’Artés (skarbnik króla Jana I; Llibre dels àngels, Vida de Jesucrist), Sança d'Arenós (hrabina de Prades; Llibre de les dones), Hug de Llupià (biskup Tortosy i Walencji, Pastorale), królowa Maria de Luna (Scala Dei) czy wreszcie Benedykt XIII (Psalterium alias Laudatorium). Ponadto Eiximenis działał jako komisarz apostolski krucjaty walencko-majorkańskiej przeciw północnoafrykańskim piratom w latach 1397-1399. W latach 1397 i 1398 był członkiem złożonej z wybitnych intelektualistów z całej Korony Aragonii komisji teologicznej, której celem było doradzanie królowi Marcinowi I w kwestii schizmy zachodniej, a w 1404 roku zaangażował się w fundację franciszkańskiego klasztoru św. Ducha w Gilet, którego najważniejszą donatorką była Maria de Luna. Cztery lata później Eiximenis doczekał się wreszcie nagrody za trud całego życia, został bowiem wezwany przez awiniońskiego papieża Benedykta XIII (Aragończyka z pochodzenia) na sobór zwołany w Perpignan, w tamtym czasie należącym do Korony Aragonii, gdzie otrzymał godność patriarchy Jerozolimy oraz biskupa Elny, to jest Perpignan. Niestety nie było mu dane zbyt długo cieszyć się tytułami ani obecnością na papieskim dworze - zmarł na początku 1409 roku. Między 25 i 26 kwietnia został opracowany wspomniany wyżej inwentarz post obitum pozostawionej w Walencji biblioteki, której franciszkanin nie zdążył już sprowadzić do nowej siedziby.

Do najważniejszych dzieł Katalończyka należy suma teologiczna Lo Crestià, napisana w stylu powstających w XIII wieku opracowań, ale w odróżnieniu od nich

24 Na przykład Księga aniołów rozpoczyna się od takiego oto stwierdzenia: „Anielska natura jest tak wzniosła [...], że wykracza poza nasze rozumienie w stanie, w jakim obecnie się znajdujemy w tym śmiertelnym życiu, w taki sposób, że o anielskiej wzniosłości i godności nie możemy myśleć, pisać ani mówić właściwie" (I, 1).

25 Francesc Eiximenis i la Casa Reial..., s. 18-55. 
nie po łacinie, a w języku ludowym, czyli katalońskim. Z zaplanowanych trzynastu tomów powstały jedynie cztery, udostępniane do publicznego wglądu przez radę miasta Walencji: Primer llibre del Crestià (Pierwsza księga Chrześcijanina; ok. 1379_ 1381), Segon llibre del Crestià (Druga księga Chrześcijanina; ok. 1382-1383), Terç llibre del Crestià (Trzecia księga Chrześcijanina; ok. 1384) i Dotzè llibre del Crestià (Dwunasta księga Chrześcijanina; ok. 1385-1386; 1391). Ogłoszona w 1392 roku Księga aniołów miała początkowo stanowić jedną z nienapisanych części tego zakrojonego na wielką skalę, choć niezrealizowanego projektu.

\section{Księga aniołów: dzieło i jego kontekst}

Księga aniołów składa się z pięciu części - traktatów lub ksiąg, jak je nazywa autor poprzedzonych dedykacją dla królewskiego skarbnika Pere d’Artés. Część pierwsza w osiemnastu rozdziałach traktuje o „aniołach oraz ich wzniosłej i doskonałej naturze"26 i ma charakter ogólny, wprowadza w materię poruszaną w całej Księdze. Wyjaśnia, czym jest istota anielska w odniesieniu zarówno do aniołów dobrych, jak i złych, czyli diabłów, jakie są jej cechy konstytutywne i w jaki sposób została stworzona przez Boga, dowodzi również istnienia aniołów w niebie i na ziemi oraz zapowiada część drugą, podając imiona aniołów oraz zależności między anielskimi istotami. Przekład tej części udostępniam Czytelnikom we fragmentach, z nadzieją, że jej lektura zachęci do przyszłego obcowania z całością traktatu.

Część druga w siedemnastu rozdziałach przedstawia anielską hierarchię („prześwietny porządek”), czyli opierając się na ustalonej przez Pseudo-Dionizego strukturze chórów i stopni anielskich, omawia naturę Serafinów, Cherubinów, Tronów, Panowań, Zwierzchności, Potęg, Mocy, Archaniołów i Aniołów. Wykład doktrynalny przeplata pouczającymi exemplami, takimi jak opowieść o Maurycym, mnichu z Canterbury, który prosił Trony o wyjaśnienie przyczyny niesprawiedliwości na świecie, a został skarcony za niezdrową ciekawość, bowiem nie jest rzeczą ludzką rozumieć wyroki Pana (II, 5).

Część trzecia, najobszerniejsza, mająca pięćdziesiąt dziewięć rozdziałów, omawia „gorliwą służbę” aniołów, to jest podejmowane przez nich działania na rzecz człowieka, takie jak opieka, pocieszenie czy obrona. W tym miejscu znajdziemy również rozważania na temat śmierci Zbawiciela, symboliczne objaśnienie znaczenia krzyża świętego oraz porady dotyczące modlitwy. Pobożny wywód urozmaicają opowieści o charakterze moralizatorskim i reformatorskim, wskazujące na niebezpieczeństwa wynikające ze złych rządów (III, 14), nadawania zbyt młodym ludziom godności

26 Wszystkie cytaty z Księgi aniołów w tłumaczeniu własnym. Jeśli nie podano inaczej, źródłem dla cytowań są skolacjonowane rękopis ze zbiorów Biblioteca Nacional de España ms. 73 (XV w.) oraz dwa inkunabuły Llibre dels àngels wydane w Barcelonie w 1494 roku, jeden przez Joana Rosenbacha, a drugi - Pere Miquela. 
kościelnych (III, 16), nieprzestrzegania przez duchownych zalecenia prowadzenia skromnego życia (III, 17) czy symonii (III, 50).

Część czwarta, o „żarliwym zwycięstwie”, w pięćdziesięciu sześciu rozdziałach podejmuje zagadnienia związane ze stworzeniem aniołów i ich funkcjami w niebie, czyśćcu, piekle i na ziemi. Opowiada również o upadku diabłów, wymienia ich imiona, charakteryzuje relacje $\mathrm{z}$ aniołami i między sobą, a także przedstawia sposoby, do jakich demony się uciekają, by kusić człowieka.

Część piąta i ostatnia, w czterdziestu ośmiu rozdziałach, została w całości poświęcona archaniołowi Michałowi, „szlachetnemu przywódcy” wszystkich aniołów.

Eiximenis spisał traktat w Walencji, w roku 1392, to jest już po ukończeniu prac nad pierwszymi trzema i dwunastą częścią Chrześcijanina, a ponieważ zapowiada w nich zawartość pozostałych tomów, wiemy, że Księga aniołów realizuje jeden z tematów zaplanowanych na tom ósmy. W pomieszczonej w preambule do Primer llibre del Crestià prezentacji całego dzieła możemy przeczytać, że miało ono wyjaśniać, jak Bóg podnosi z upadku człowieka dzięki swej „potędze, mądrości i miłosierdziu, które ukazuje w rzeczach stworzonych, rządzonych i uporządkowanych w odpowiednie stany"27. Opracowany przez Curta Wittlina przegląd autonawiązań w obrębie Chrześcijanina uściśla z kolei treść tomu w odniesieniu do kwestii aniołów i demonów ${ }^{28}$. Wewnętrzne referencje odpowiadają pierwszym czterem częściom Księgi aniołów - przy założeniu, że zagadnienie „natury anielskiej” obejmuje również wykład na temat hierarchii niebiańskiej - a pomijają część piątą. Oznacza to, że materiał do pierwszych czterech części został zebrany i opracowany jeszcze przed 1379 rokiem, czyli datą powstania Primer.

\section{Źródła}

Księga aniołów, podobnie jak inne traktaty Eiximenisa, zaskakuje niezwykłą obfitością cytowań i odniesień bibliograficznych, które przy pierwszym spotkaniu z tekstem wywołują podziw nad erudycją autora. Po bliższym przyjrzeniu się źródłom z niemałym zaskoczeniem odkrywamy jednak, że niekoniecznie zawierają one przypisywane im treści, a nawet niekoniecznie istnieją. Dodatkowo część cytatów została ukryta, to znaczy podana bez wskazania autora albo ze wskazaniem generycznym - „filozofowie”, „doktorzy” - które nie ułatwia rozpoznania przywoływanego dzieła. Nie oznacza to bynajmniej, że Eiximenis podchodził do własnej pracy pisarskiej z niedbałością lub dobierał cytaty na chybił trafił, opierając się na niskiej jakości kompilacjach i opracowaniach, ponieważ w wielu przypadkach zmyślone

$27 \quad$ F. Eiximenis, Lo Crestià..., s. 41.

28 C. Wittlin, Referències internes en les obres de Francesc Eiximenis: indicis de quins llibres, sobre quins temes, tenia planejat l'autor, Narpan.net (2009), https:/www.narpan.net/bibliotecadigital/articles/ cat_view/85-wittlin-curt.html (dostęp: 2.01.2020). 
lub niewłaściwie opisane źródła mają wskazywać na ukryty podtekst krytyczny lub żartobliwy ${ }^{29}$. Jednocześnie trudno dziś znaleźć klucz, jeśli takowy w ogóle istnieje, do wszystkich niepewnych fragmentów ${ }^{\mathbf{3 0}}$. Dlatego, aby wydać jednoznaczną ocenę, potrzebna jest szczegółowa analiza wszystkich Eiximeniańskich źródeł, której zaczątek w odniesieniu do Księgi aniołów przedstawiam poniżej.

Imponująca lista nazwisk i tytułów pojawiających się w twórczości Eiximenisa bez wątpienia świadczy o jego literackim i naukowym obyciu, będącym owocem wieloletnich studiów w licznych ośrodkach akademickich Europy. Należy przy tym pamiętać, że zakony mendykanckie posiadały swoje własne studia generalia, niewłączone w działalność świeckich uniwersytetów, dlatego zarówno franciszkanie, jak i dominikanie wpisywali się na uniwersytety jedynie w sytuacji, kiedy chcieli uzyskać stopień mistrza. Studia zakonne specjalizowały się w teologii (studia poświęcone Biblii oraz Sentencjom Piotra Lombarda), uniwersytety zaś posiadały wydziały sztuk wyzwolonych, prawa cywilnego i kanonicznego oraz medycyny. Eiximenis jako franciszkanin był z pewnością bardziej zainteresowany programem studiów teologicznych, o czym świadczy wspominany wcześniej inwentarz post obitum. W bibliotece Eiximenisa ${ }^{31}$ znajdowały się liczne traktaty dotyczące teologii i logiki, ponadto na uwagę zasługują trzy bogate kolekcje komentarzy do Sentencji oraz traktaty autorstwa franciszkańskich uczonych z XIII i pierwszej połowy XIV wieku: Roberta Grosseteste’a, Aleksandra z Hales, Giovanniego da Ripa, Jana Dunsa Szkota, w tym również autorów kontrowersyjnych: Piotra Jana Oliviego oraz Wilhelma Ockhama i ockhamistów. Zaskakuje całkowity brak dzieł autorów klasycznych oraz pism ojców Kościoła, zrównoważony w pewien sposób przez prowadzone przez Eiximenisa wykazy tematyczne interesujących go kwestii zawierające powiązane z nimi cytaty. W nich też można upatrywać pierwszego źródła opisywanych wyżej nieścisłości. Dla przykładu: dzięki inwentarzowi wiemy, że Eiximenis znał pisma Grosseteste’a, jednak zamieszczone w pierwszej części Księgi aniołów odwołania do komentarza tego autora do De divinis nominibus Pseudo-Dionizego są nieścisłe, ponieważ w tym akurat dziele nie ma zapowiadanych treści. Można zatem przypuszczać, że sporządzając notatki na temat aniołów, Eiximenis niepoprawnie oznaczył tytuł lub w ogóle go nie zamieścił, zachowując jedynie nazwisko autora i cytat lub jego parafrazę, a następnie, gdy pisał swój traktat, nie sięgnął do tekstu oryginalnego, lecz oparł się na własnym wykazie lub uzupełnił tytuł z pamięci. Innym możliwym rozwiązaniem problemu jest założenie, że kopia komentarza do De divinis nominibus, którą dysponował franciszkanin, rzeczywiście zawierała cytowane fragmenty, ale należały one do innego dzieła (lub nawet innego autora), co jednak nie zostało w tekście explicite wskazane.

29 Na temat krytyki politycznej zaszyfrowanej pod fantastyczną bibliografią w Dotzè Eiximenisa por. C. Wittlin, Francesc Eiximenis i les seves fonts, „Llengua i literatura” 11 (2000), s. 41-108.

30 Por. A. de Riquer, Notes sobre la peculiar erudició clàssica de fra Francesc Eiximenis, „Boletín de la Real Academia de Buenas Letras de Barcelona" 43 (1991-1992), s. 51-58.

31 J. Monfrin, La Bibliothèque..., s. 241-287. 
W pojedynczych przypadkach Eiximenis podaje dokładne (jak na swoje czasy) adresy bibliograficzne, to znaczy nazwisko autora, tytuł dzieła i numer rozdziału, na przykład „Vercellensis comentant Dyonis De divinis nominibus [...] capitol VI”, lecz zwykle ogranicza się do samego imienia, na przykład „sanct Dyonis”, „Lactancius”, „Ricardus”, lub przydomka, jak w przypadku nawiązań do wymienianego już Roberta Grosseteste’a, nazwanego „Liconensis”, albo Piotra Lombarda, określanego zgodnie z tradycją epoki „Mestre de les Sentències”. Imię lub przydomek bywają uzupełniane o tytuł traktatu, na przykład „Strabus Super Genesim”, co jak pamiętamy, niekoniecznie oznacza, że przywołane przez autora myśli rzeczywiście znajdziemy we wskazanym tekście. Zdarza się jednak, że nawet szczegółowe odwołanie bibliograficzne nie spełnia swoich funkcji, tak jak we wspomnianym wyżej przykładzie dotyczącym Thomasa Gallusa - rozdział VI komentarza do De divinis nominibus nie zawiera bowiem podanego cytatu. Czy można zatem przyjąć, że Eiximenis, sporządzając notatki z różnych komentarzy do Imion boskich, sam się w nich pogubił, stąd powtarzający się błąd w cytowaniach z Grosseteste’a i Gallusa? Czy też w przypadku Gallusa mamy do czynienia z materiałem z drugiej ręki i to w nim doszło do przekłamań? Jak było w tym konkretnym przypadku, na razie nie wiadomo, pewne jest jednak, że kopiowanie błędów z cudzych opracowań zdarzało się Eiximenisowi (i nie tylko jemu) nie raz, jak choćby w rozdziale X pierwszej części Księgi aniołów, w którym zdanie zaczerpnięte przez Jana Damasceńskiego z Nemezjusza Eiximenis przypisuje św. Augustynowi.

Kolejnym problemem jest brak jakichkolwiek przydatnych wskazań źródłowych, ponieważ Eiximenis, powołując się na przykład Grzegorza Wielkiego ${ }^{32}$, chętnie posługuje się określeniami generycznymi, takimi jak sancts, filòsofs lub doctors, doprecyzowując je niekiedy o równie niewiele mówiące ograniczenia czasowe antics lub moderns. Możemy jedynie przypuszczać, że gdy wspomina „współczesnych doktorów", ma na myśli któregoś z ockhamistów, jeśli nie samego Wilhelma Ockhama, jako że inne pisma Eiximenisa ujawniają jego sympatię w stosunku do tego ruchu, z zachowaniem rzecz jasna daleko idącej powściągliwości ze względu na wiążące się z nim kontrowersje. Wobec trudności dogmatycznych Eiximenis przyjmuje postawę ostrożną w tym sensie, że zazwyczaj nie wskazuje wprost doktryn, z którymi się nie zgadza. Choć zdarzają się i w tej kwestii wyjątki, jak w Księdze aniołów (I, 4), w której decyduje się na otwartą polemikę z paryskim potępieniem z 1277 roku tezy o powiązaniu działania anioła z miejscem jego przebywania. Najczęściej jednak źródeł koncepcji krytykowanych, ale jego zdaniem słusznych, nie ujawnia, co można prześledzić, porównując kolejne rozdziały Księgi aniołów z zagadnieniami Sumy teologicznej Tomasza z Akwinu dotyczącymi kwestii anielskich. Eiximenis wplata sparafrazowane rozważania Akwinaty w swój wywód tak zręcznie, że nie zaburzają ani płynności dyskursu, ani spójności stylistycznej języka. Co ciekawe w momencie ogłoszenia Księgi aniołów, to jest w 1392 roku, przemilczanie

32 C. Wittlin, Com Eiximenis tradueix i interpreta "segons que em serà vejares que sia pus profitós als lligents”. Teoria i pràctica d'una metodologia dubtosa, „Estudis romànics” 38 (2016), s. 373. 
autorstwa Sumy trzeba uznać za anachronizm, ponieważ już od połowy XIV wieku tomizm był przez Kościół akceptowany jako koncepcja filozoficzna w sporze z ockhamistami ${ }^{33}$. Czy Eiximenis był tego świadom, nie wiemy. Prawdopodobnie, pisząc traktat, korzystał z notatek opracowanych dużo wcześniej, jeszcze przed powstaniem pierwszego tomu Chrześcijanina (1381), w którym zapowiada tom ósmy, poświęcony właśnie aniołom.

Bez wątpienia liczne źródła bibliograficzne wskazywane przez Eiximenisa są wytworem jego fantazji, jak udowodnił już w 1696 roku Nicolás Antonio, który w Bibliotheca Hispana Vetus opublikował listę niemal stu referencji bibliograficznych zaczerpniętych z Chrześcijanina, a nieznajdujących pokrycia w istniejącej literaturze ${ }^{34}$. Odwoływanie się do fikcyjnych dzieł czy autorów nie stanowiło praktyki odosobnionej w czasach Eiximenisa, a wsparcie autorytetów dawnych, nawet jeśli zostały tylko zmyślone, dodawało powagi rozważaniom autora i pozwalało na przemycenie kontrowersyjnych pomysłów bez narażania się na krytykę ze strony Kościoła czy władców Korony Aragonii ${ }^{35}$. Również w Księdze aniołów pojawiają się pisma widma, są to dwa listy Orozjusza, jeden Ad Victorium Monachum (I, 15) i drugi Do Fabrycja patriarchy (I, 17). Ponieważ nie zawierają niczego, co sprzeciwiałoby się ortodoksji, należy przyjąć, że celem ich „stworzenia” było dodanie powagi wykładowi.

Jedynym pewnym i niebudzącym wątpliwości źródłem jest Biblia, na której Eiximenis wspiera się zarówno we fragmentach doktrynalnych, jak i narracyjnych, ze szczególnym upodobaniem przytaczając ilustracyjne opowieści. W rozdziale VII, w którym wyjaśnia, że anioły, będące ze swej natury bezcielesne, nie jedzą ani nie piją, odwołuje się do opisanego w Księdze Rodzaju poczęstunku zaoferowanego przez Abrahama anielskim gościom oraz podróży Tobiasza w towarzystwie archanioła Rafała z Księgi Tobiasza. W obydwu fragmentach Pismo Święte podaje, że anioły jadły i piły w obecności ludzi, co stoi w sprzeczności z tezą o ich czysto duchowej naturze głoszoną przez Eiximenisa. Dlatego franciszkanin czuje się w obowiązku ratować autorytet Biblii za pomocą dość kuriozalnej racjonalizacji, objaśniając, że „choć wspomniane święte anioły przyjmowały pokarm i go spożywały, przekształcały go w inną materię poza sobą i potajemnie [...] przez sprytną sztukę”, czyli dzięki jakiejś bliżej niesprecyzowanej umiejętności, niedostępnej ludzkiemu poznaniu.

33 Kościół oceniał działalność ockhamistów wysuwającą na pierwszy plan filozofię i nauki świeckie jako „rujnując[ą] gmach tradycyjnej teologii” (Z. Kuksewicz, Zarys filozofii średniowiecznej, Warszawa 1973, s. 389-390). Dlatego po fali krytyki w XIII wieku zaakceptował w wieku XIV arystotelizm, a także tomizm, uznawany od tej chwili za zaplecze teoretyczne teologii (ibidem).

34 C. Wittlin, ¿És veritat que Francesc Eiximenis «inventava autors, títols de llibres, i noms de reis $i$ d'altres persones» i que patia d’una «ingenuïtat i credulitat sense límits»?, w: Actes del Tretzè Col-loqui Internacional de Llengua i Literatura Catalanes: Universitat de Girona, 9-12 de setembre de 2003, coord. S. Martí et al., vol. 3, Barcelona 2007, s. 35 . 


\section{Język}

Na osobny komentarz zasługuje również język popularyzatorskich traktatów Eiximenisa. Jako magister teologii, obyty z pismami filozoficznymi swoich czasów, posługuje się scholastyczną metodą wykładu zapożyczoną od autorów wielkich sum. Wywód buduje w sposób uporządkowany, to jest wychodzi od tezy, następnie przedstawia argumenty względem niej przeciwne, a na końcu obala je po kolei, dowodząc słuszności tezy początkowej. Dla przykładu: komentowany przed chwilą rozdział VII zaczyna się od przypomnienia tezy: „anioł nadaje czynności życia ciału, jakie przyjmuje”, dalej zostają wyliczone kontrargumenty, to jest przykłady z Biblii, w których anioły jedzą i piją, oraz dowody na zdolności prokreacyjne diabłów zaczerpnięte pośrednio ze św. Augustyna („Tak jak u św. Augustyna, który mówi często o inkubach i sukubach”) oraz z literatury („często zdarzało się, że diabeł, pokładając się z niewiastą, płodził ludzi, jak to czytamy zwłaszcza o Merlinie”). Szczególnie ta ostatnia kwestia budzi żywe zainteresowanie autora, dlatego w części poświęconej obalaniu kontrargumentów szczegółowo opisuje mechanizm umożliwiający płodzenie diabelskiego potomstwa. Rozdział kończą wnioski wyciągnięte z udowodnionej tezy początkowej, poszerzające zakres jej stosowania.

Zawartość pierwszej części Księgi aniołów ze względu na poruszany temat może się wydawać aż nazbyt erudycyjna jak na dzieło popularyzatorskie, niemniej jednak Eiximenis przystosowuje treść doktrynalną do kompetencji intelektualnych świeckich czytelników ${ }^{\mathbf{3 6}}$, „mówiąc nie uczenie, a raczej jak dla świeckich i w ogólności” (I, 2). Wiele kwestii teologicznych pomija, uznając je za zbyt spekulatywne, na przykład nie analizuje różnicy między określeniami „rozumny” i „intelektualny” w odniesieniu do aniołów, pozwalając czytelnikowi sądzić, że są względem siebie synonimiczne. Te zaś problemy, które omawia, upraszcza, tak jak zagadnienie łaski przekazanej (lub nie - według niektórych teologów) aniołom zaraz po stworzeniu, stwierdzając po prostu, że „nie zostały stworzone w łasce uświęcającej” (I, 15). Modyfikuje również styl w zależności od powagi poruszanego tematu. W kolejnych częściach Księgi aniołów Eiximenis obudowuje kwestie teologiczne przykładami własnej inwencji albo zaczerpniętymi z lektur, folkloru i życia codziennego - tak jak w części trzeciej, dotyczącej anielskiej służby, w której znajdziemy wiele opowieści zebranych z najróżniejszych źródeł, jak choćby Historia Irlandii Bedy. Albo w części czwartej, w której franciszkanin podaje przedziwną, najwyraźniej niezrozumiałą dla kopisty formułę egzorcyzmu mieszającą imiona boskie należące do bardzo odmiennych tradycji: „Maledicte diabole, recognosce sententiam tuam et da honorem Deo vivo et vero [...] per ista sacra nomina Dei: $\dagger$ Jothe $\uparrow$ Eloy $\uparrow$ Helee $\uparrow$ Sabaot $\uparrow$ Adonay $\uparrow$ Feyzos $\uparrow$ Agy$\mathrm{os} \uparrow$ Otheos $\uparrow$ Isquyros $\uparrow$ Sot $\uparrow$ Emanuel $\uparrow$ Tetagramaton $\uparrow$ Onguas $\uparrow$ Ongla $\uparrow$ Rogla $\uparrow$ Dreas $\uparrow$ Spes $\uparrow$ Albot $\uparrow$ Fortis $\uparrow$ Astiel $\uparrow$ Succurre $\dagger$ Pater $\uparrow$ Sanctissime $\dagger$ isti

36 D.J. Viera, J. Piqué, L’estil en l’obra de Francesc Eiximenis, w: Actes del Tretzè Col-loqui Internacional de Llengua i Literatura Catalanes..., s. 441, 443. 
homini [...]" $(\mathrm{IV}, 44)^{37}$. Najciekawsza pod względem warsztatu popularyzatorskiego jest część piąta, poświęcona w całości archaniołowi Michałowi, która stanowi kompilację materiałów hagiograficznych i biblijnych, ale również popularnych, takich jak modlitwy do archanioła czy przypisywane mu przepowiednie (V, 38-41). W tych częściach Księgi aniołów, w których pojawiają się takie elementy jak humor czy zajmujące exempla, Eiximenis wyraźnie wzoruje się na kazaniach pisanych w językach ludowych dla laików, których styl przyswoił sobie podczas pracy nad kolejnymi tomami Chrześcijanina ${ }^{38}$. Trudno oczywiście stwierdzić, czy Eiximenis wierzył we wszystkie opisywane $w$ exemplach cuda i zdarzenia nadnaturalne. $Z$ pewnością widział w nich doskonały, zapadający w pamięć materiał pedagogiczny, pobudzający wyobraźnię czytelników słabo wykształconych, a dla uczonej publiczności stanowiący formę rozrywki - tak jak przytoczona wyżej formuła egzorcyzmu, której nieortodoksyjny charakter musiał być oczywisty dla wykształconego odbiorcy. Poza tym Eiximenis, obdarzony niezwykłą intuicją psychologiczną, której dowody daje również w innych swoich traktatach, z pewnością miał świadomość tego, że wiara w sprawczość ceremonii, znaków magicznych i słów działa na zasadzie autosugestii, a połączona z modlitwą do Boga przynosi więcej korzyści niż szkody ${ }^{39}$.

Na zakończenie warto się przyjrzeć obranym przez Eiximenisa strategiom translatorskim. Ponieważ Księga aniołów została pomyślana jako traktat „dla osób prostych i świeckich, nie zaś dla uczonych i wielkich duchownych” (I, 12), łacińskie cytaty pojawiają się w niej rzadko i w większości są tłumaczone na język kataloński. Niemniej jednak Eiximenis, nie będąc zwolennikiem przekładów literalnych, dopuszczał się licznych nadinterpretacji, wychodził bowiem z założenia, że rolą tłumacza jest oddanie sensu zawartego w oryginale, „wytłumaczenie" intencji autora, które dla czytelnika - zwłaszcza nieuczonego - mogą być niejasne. W preambule do Primer definiuje przyjętą strategię translatorską, wzorując się prawdopodobnie na Grzegorzu Wielkim ${ }^{40}$, w następujący sposób: „zamierzam przestrzegać zasad świętych ojców i doktorów [...], nie będę zatem tłumaczyć na nasz język ani objaśniać [łacińskich cytatów] po żydowsku [tzn. dosłownie], wedle litery, słowo po słowie i szczegółowo, ale wedle ich prawdziwego sensu, w skrócie i słowami, które są bardziej zrozumiałe i przynoszą więcej korzyści czytelnikom”"41 . I rzeczywiście:

„Złośliwy diable, przypomnij sobie swój wyrok [tj. potępienie - R.S.] i oddaj cześć Bogu żywemu i prawdziwemu [...] przez te święte imiona Boga: $\dagger$ Jothe $\uparrow$ Eloy $\dagger$ Helee $\uparrow$ Sabaot $\dagger$ Adonaj $\uparrow$ Feyzos $\uparrow$ Agyos $\uparrow$ Otheos $\dagger$ Isquyros $\uparrow$ Sot $\uparrow$ Emanuel $\uparrow$ Tetagramaton $\uparrow$ Onguas $\uparrow$ Ongla $\uparrow$ Rogla $\uparrow$ Dreas $\uparrow$ Spes $\uparrow$ Albot $\uparrow$ Fortis $\uparrow$ Astiel. Pomóż, Ojcze Przenajświętszy, temu człowiekowi [...]”. Transkrypcja oryginału za C. Wittlin, ¿És veritat...?, s. 47.

39 C. Wittlin, ¿És veritat...?, s. 47-49. Dla przykładu: w rozdziale 284 Dotzè Eiximenis wyjaśnia, że ustalenie sprzyjających ascendentów astrologicznych wzmaga odwagę i pewność siebie dowodzącego oblężeniem, ponieważ „wyobraźnia często daje sercu odwagę albo słabość”, F. Eiximenis, Dotzè del Crestià, València: Lambert Palmart, 1484.

40 C. Wittlin, Com Eiximenis..., s. 372-373.

${ }^{41} \quad$ F. Eiximenis, Lo Crestià..., s. 37. 
podane w pierwszej części Księgi aniołów tłumaczenia łacińskich cytatów często odbiegają od oryginału, tak jak w rozdziale XIV, w którym okrojony na potrzeby wywodu fragment Psalmu 100(99) „Scitote quoniam Dominus ipse fecit nos” został przełożony tak: „co oznacza, aby każdy zrozumiał: wiedz, że Bóg nasz Pan jest prawdziwym Bogiem i on jest Tym, który nas stworzył, bo nie zostaliśmy poczęci tak jak ludzie drogą naturalną” (I, 14). Bez wątpienia nie jest to tłumaczenie „wedle litery”, ale trudno nie zauważyć, że brakuje mu skrótowości, zastąpionej wykładnią „prawdziwego sensu”. Jednak niesłusznie postąpiłby ten, kto oskarżałby Eiximenisa o rozmyślne manipulowanie znaczeniem. Podawane przez niego wykładnie cytatów wpisują się w tradycję interpretacji biblijnych dopuszczających rozszerzanie podstawowego, dosłownego znaczenia tekstu. Niekoniecznie są też oryginalnym wkładem franciszkanina: pojawiająca się w Księdze aniołów formuła „ço és” (to jest; co znaczy) umieszczana po łacińskich przytoczeniach jest dosłownym tłumaczeniem formuły „id est” (względnie „scilicet”) powszechnie wykorzystywanej w komentarzach do wprowadzania interpretacji.

Wsparta tradycją swoboda w traktowaniu łacińskich cytatów bywała jednak zgubna, gdy prowadziła Eiximenisa do kuriozalnych pomyłek, które choć dość rzadkie, skłaniają po raz kolejny do refleksji nad warsztatem pisarskim autora. W rozdziale XIV dowiadujemy się, że według Strabusa „Bóg stworzył na początku świata cztery rzeczy, to jest: niebo empirejskie, czas, pierwotną materię, z której powołał inne rzeczy, oraz, prócz owych trzech, stworzył jeszcze naturę anielską" (I, 14), jednak w oryginale znajdziemy jedynie dwie rzeczy: „Proinde duas res fecit Deus ante omne tempus, angelicam creaturam et materiam informem”42 . Z wcześniejszych passusów Super Genesim (a także Księgi aniołów) wiemy, że Bóg stworzył niebo empirejskie, nigdzie jednak nie wspomina się o czasie. Czyżby Eiximenis zinterpretował „ante omne” jako „przed człowiekiem”, wstawił pauzę przed „tempus”, a „duas res” zignorował? Jest to możliwe, ponieważ podobne omyłki czy nadinterpretacje pojawiają się również w innych jego traktatach, na przykład w Primer, w którym czytamy, że „Orygenes poprawił tłumaczenie siedemdziesięciu dwóch [Septuagintę] z pomocą dwóch szlachetnych mężów, z których jeden zwał się Astericus, a drugi Obelus" (rozdz. 314). I chociaż od razu nasuwa się skojarzenie z komiksowymi postaciami Asteriksa i Obeliksa, źródłem pomyłki jest najprawdopodobniej nieuwaga Eiximenisa, który błędnie zinterpretował określenia odnoszące się do znaków typograficznych: asteriscus $\left(^{*}\right)$ oraz obelus $(\div)$, i w ten sposób powołał do życia pomocników Orygenesa ${ }^{43}$.

Niezależnie od tego, jak bardzo by nas dziś dziwiły decyzje translatorskie Eiximenisa, trzeba mu przyznać, że wysiłek włożony w dostosowanie treści doktrynalnych do możliwości świeckich czytelników, lekki styl oraz liczne, przyciągające uwage przykłady i opowieści sprawiły, że Księga aniołów odniosła w swoim czasie

42 W. Strabus, Glosa ordinaria super Genesim et Exodum, w: idem, Opera omnia, ed. J.-P. Migne, t. 2, Parisiis 1852 (Patrologiae Cursus Completus. Series Latina [PL], 113), 69B.

43

C. Wittlin, Com Eiximenis..., s. 381. 
niebywały sukces. Zamieszczony poniżej przekład jej fragmentów stanowi niewielką próbkę literackiego kunsztu autora.

\section{Nota do przekładu polskiego}

Traktat Francesca Eiximenisa zatytułowany w oryginale Llibre dels àngels nie doczekał się jeszcze pełnej edycji krytycznej. Do tej pory ukazały się zaledwie dwie księgi, na dodatek jako niezależne publikacje opracowane przez różnych badaczy: w 1983 roku księga piąta zatytułowana De Sant Miquel arcàngel ${ }^{44}$ oraz w 2003 roku księga czwarta - Ángels e demonis ${ }^{45}$. Z tej przyczyny tłumaczenie na język polski zostało wykonane na podstawie trzech skolacjonowanych tekstów: inkunabułu wydanego w drukarni Joana Rosenbacha w Barcelonie w 1494 roku (Biblioteca Nacional de Catalunya, sygn. Bon. 7-IV-28), inkunabułu z drukarni Pere Miquela wydanego w tym samym roku w tym samym mieście (Biblioteca Nacional de Catalunya, sygn. 11-VII-6) oraz datowanego na wiek XV rękopisu przechowywanego w Biblioteca Nacional de España (ms. 73).

Zarówno rękopis, jak i inkunabuły podchodzą do kwestii interpunkcji w sposób swobodny, dlatego pierwszą trudnością, z jaką przyszło mi się zmierzyć, było ustalenie podziału tekstu na zdania. Podziału nie zawsze oczywistego, ponieważ Eiximeniańska fraza bywa długa, przeładowana wtrąceniami i powtórzeniami, w których sam autor czasem się gubi i niefrasobliwie zmienia podmiot w obrębie jednej całości myślowej. Niewątpliwie naśladuje w ten sposób język mówiony, choć być może nieświadomie, ale z pewnością nie ułatwia zadania czytelnikowi. Widać to zresztą w podziale zaproponowanym przez barcelońskich wydawców, którzy często decydowali się na zakończenie zdania, nie bacząc ani na jego treść, ani sens. Opracowując polski przekład, starałam się zachować tam, gdzie to było możliwe, oryginalny styl Eiximenisa, podporządkowując go współczesnym zasadom interpunkcji. Jeśli jednak zdania okazywały się nieczytelne, czy to z powodu długości, czy nagromadzenia treści, dzieliłam je na krótsze według przewodniego tematu w każdej części. W podobny sposób rozwiązywałam problem niezgodności podmiotów: w zdaniach długich wprowadzałam podział, tak by nie zaburzać logiki dyskursu, natomiast w krótszych podmioty uzgadniałam. Wychodzę z założenia, że przekład ma być przede wszystkim zrozumiały, przekazywać wyłożoną w oryginale treść, czemu dosłowne tłumaczenie błędów gramatycznych nie sprzyja. Przekład nie jest też odpowiednim materiałem do dogłębnej analizy stylu pisarskiego, który można badać jedynie na podstawie tekstu oryginalnego.

44 F. Eiximenis, De Sant Miquel arcàngel: el quint tractat del "Libre dels àngels", introducció, edició i apèndixs de C. Wittlin, Barcelona 1983.

45 E. Eiximenis, Àngels e demonis, edició i comentaris de S. Martí, Barcelona 2003. 
Z tych samych względów słownictwo Księgi aniołów jest dużo bardziej zróżnicowane niż Llibre dels àngels. Średniowieczni autorzy - a Eiximenis, mimo kontaktów z bujnie rozkwitającym środowiskiem walenckich humanistów, zalicza się do takich nie boją się powtórzeń i potrafią oddać rozmaite treści za pomocą tego samego zestawu podstawowych czasowników (robić, mieć, dać itp.). Eiximenis wpisuje się w tę tradycję, bo chociaż w zależności od potrzeb i skomplikowania omawianych kwestii rozbudowuje leksykę, nie ucieka się do synonimów, kiedy wystarczy zwykłe fer (robić) o bardzo szerokim polu znaczeniowym. Język polski takiego nagromadzenia powtórzeń nie znosi, dlatego oryginalną frekwencję występowania poszczególnych wyrazów w tekście mogłam zachować jedynie w niewielkim zakresie. Mam świadomość, że wprowadzam w ten sposób kolejną zmianę w stylu autora, ale uważam, że jest to zabieg konieczny z punktu widzenia współczesnego czytelnika.

Na zakończenie chciałabym zwrócić uwagę na jeszcze jedną cechę oryginalnego dzieła, wynikającą z przyjętych przez autora założeń co do celu traktatu. Księga aniołów powstała, aby szerzyć kult aniołów wśród odbiorców nieuczonych, lecz piśmiennych, co ogranicza krąg czytelników do bogatego mieszczaństwa i arystokracji. Nieuczoność oznacza tu jedynie brak wstępnych studiów teologicznych, a nie brak podstawowego wykształcenia. W związku z tak zdefiniowanym profilem odbiorcy Eiximenis stara się nie posługiwać skomplikowaną terminologią, nie tylko scholastyczną, ale również tą należącą do zagadnień nauczanych w ramach trivium. Dlatego na przykład tłumaczy znaczenie pojęcia „hiperbola” albo upraszcza teologiczne subtelności. Współczesny angelolog, który mógłby mieć wątpliwości co do stopnia ortodoksyjności podawanej przez franciszkanina wykładni, musi o tym pamiętać i traktować Eiximeniańską nomenklaturę teologiczną z dużą rezerwą. 


\title{
Księga aniołów
}

\author{
Księga pierwsza
}

\section{Rozdział I}

Oto rozpoczyna się Księga aniołów ułożona przez czcigodnego mistrza Francesca Eiximenisa z Zakonu Braci Mniejszych, magistra świętej teologii, zaś dalej następuje rozdział pierwszy, który traktuje krótko i w ogólności o wzniosłości anielskiej natury.

Anielska natura jest tak wzniosła i cudowna i tak wspaniale stworzona, wywyższona, uporządkowana i wyniesiona w chwale przez naszego Pana Boga, że wykracza poza nasze rozumienie $\mathrm{w}$ stanie, $\mathrm{w}$ jakim obecnie się znajdujemy w tym śmiertelnym życiu, w taki sposób, że o anielskiej wzniosłości i godności nie możemy myśleć, pisać ani mówić właściwie, tak jak tego wymaga jej pełna chwały i wspaniała cześć. Jednak ponieważ mówienie o aniołach jest dla nas wielkim pożytkiem i koniecznością przez dług, jaki względem nich zaciągnęliśmy, oraz z powodu wielkich potrzeb i nędzy, jakie nam doskwierają w obecnym życiu, winniśmy uciekać się do Boga, a po Nim do ich czcigodnej ojcowskiej opieki i łaskawej pilności, $\mathrm{z}$ tego względu w owej księdze powiemy o nich nieco, tyle, ile dzięki łasce Pana naszego Boga będziemy zdolni, zawsze i przede wszystkim ku Jego chwale i czci, a także ku czci i zbawieniu dusz naszych, które anioły przez zrządzenie Boże mają nieustannie w swej pieczy, o czym to poniżej szczegółowo traktujemy i nauczamy w kolejnych częściach księgi.

\section{Rozdział II pokazuje, czym jest anioł sam w sobie}

Na początek trzeba, byśmy wyłożyli, czym jest anioł, ponieważ wedle zwyczaju na początku księgi winno się wyłożyć, o jakiej materii będzie w niej mowa. I winieneś wiedzieć, że chociaż w Piśmie Świętym wiele się na ten temat mówi, to tymi, którzy najgłębiej ów temat rozważyli i [najwięcej] nam przekazali, są przede wszystkim 
święty męczennik szlachetny św. Dionizy ${ }^{\mathbf{4 6}}$ w księdze, co się zowie Hierarchia anielska ${ }^{47}$, w której wykłada, że wszystkiego tego, co w niej jest o naturze anielskiej, dowiedział się od człowieka, który widział to na własne oczy, to jest od szlachetnego św. Pawła ${ }^{48}$. Bo kiedy ten został wyniesiony do trzeciego nieba i ujrzał tam hierarchie anielskie i inne szczeble niebiańskiego porządku, by o nich powiadomić Święty Kościół, wyjawił wszystko św. Dionizemu, który był znakomitym i oświeconym doktorem, a zarazem jego uczniem. Jeszcze o aniołach mówił wielki grecki doktor Damascen ${ }^{49}$ oraz Mistrz Sentencji w drugiej księdze ${ }^{50}$ i wielu innych, którzy wszyscy dali odpowiedź na pytanie postawione na początku niniejszego rozdziału, czyli czym jest anioł.

I rzeknę ci, że wedle tego, co z ich [ksiąg] zebrałem, mówiąc nie uczenie, a raczej jak dla świeckich i w ogólności, anioł jest naturą i substancją duchową, nie zaś cielesną,

46 Pseudo-Dionizy Areopagita (V/VI w.) - teolog i neoplatoński filozof chrześcijański pozostający pod silnym wpływem Proklosa, prawdopodobnie mnich syryjski, autor zbioru pism nazwanego Corpus Dionysiacum, w którego skład wchodzą: Hierarchia niebiańska, Hierarchia kościelna, Imiona Boskie, Teologia mistyczna oraz dziesięć listów.

47 W oryginale greckim to Peri tes ouranias hierarchias, choć w średniowieczu większość autorów korzystała z łacińskich przekładów zatytułowanych De coelesti hierarchia Jana Szkota Eriugeny (IX w.), Jana Saracena (XII w.) i Roberta Grosseteste’a (XIII w.) oraz licznych komentarzy. W polskim tłumaczeniu tytuł ten brzmi Hierarchia niebiańska. Por. Pseudo-Dionizy Areopagita, Hierarchia niebiańska, w: idem, Pisma teologiczne, t. 2: Hierarchia niebiańska; Hierarchia kościelna, przeł. M. Dzielska, Kraków 1999 i późniejsze wznowienia. Tytułowa niebiańska hierarchia odnosi się do porządku dziewięciu chórów anielskich, choć sam traktat omawia kwestie angelologiczne w dużo szerszym kontekście.

48 Ani Hierarchia niebiańska Pseudo-Dionizego, ani żaden z jego pozostałych tekstów nie zawierają takiego wywodu, choć sam Pseudo-Dionizy podaje się za ucznia św. Pawła. O porwaniu do trzeciego nieba św. Paweł wspomina w 2 Liście do Koryntian (2 Kor 12,2-4): „Znam człowieka w Chrystusie przed czternaścią lat, (jeźli w ciele, nie wiem, jeźli prócz ciała, nie wiem, Bóg to wie), iż takowy był zachwycony aż do trzeciego nieba. A znam takowego człowieka, (jeźli w ciele, jeźli prócz ciała, nie wiem, Bóg to wie), iż był zachwycony do raju i słyszał tajemne słowa, których się człowiekowi nie godzi mówić”. Również w traktacie Wykład wiary prawdziwej Jana Damasceńskiego, który stanowi jedno ze źródeł dla pierwszej części Księgi aniołów, znajduje się wzmianka o porwaniu św. Pawła do „trzeciego nieba”, jednak w kontekście odmiennym, bo związanym z rozważaniami na temat nieba w ogóle; por. Jan Damasceński, Wykład wiary prawdziwej, przeł. B. Wojkowski, Warszawa 1969, II, 6, s. 70. Wszystkie przekłady z Pisma Świętego za Biblią Jakuba Wujka, na podstawie: Biblia, to jest księgi Starego i Nowego Testamentu z łacińskiego na język polski przełożone. Dosłowny przedruk z autentycznéj edycyi Krakowskiéj z r. 1599, potwierdzonéj przez Ś. Stolicę Apostolską i JW księdza Arcybiskupa Gnieźnieńskiego i Poznańskiego, Bielsko-Biała 2018.

49 Jan Damasceński (ok. 675-749) - teolog, filozof chrześcijański i poeta, ostatni z ojców Kościoła na Wschodzie, autor licznych rozpraw teologicznych, z których najlepiej znaną w średniowiecznej Europie była przetłumaczona na łacinę synteza nauk teologicznych De fide orthodoxa (w polskim przekładzie Wykład wiary prawdziwej), funkcjonująca jako podręcznik dogmatyki. W tłumaczeniu Księgi aniołów posługuję się archaiczną formą „Damascen”, aby możliwie wiernie oddać język oryginału.

Piotr Lombard (ok. 1095-1159) - zwany „Magister Sententiarum”, teolog, autor Czterech ksiag sentencji (tytuł skrócony Sentencje; Libri quattuor sententiarum lub Sententiae), wykorzystywanych w średniowieczu jako podręcznik teologii na uniwersytetach w Paryżu i Oksfordzie. Rozważania dotyczące aniołów znajdują się w księdze drugiej, w dystynkcjach od II do XI; por. Piotr Lombard, Cztery księgi sentencji, t. 1, przeł. J. Wojtkowski, Olsztyn 2013, s. 336-384. 
rozumną ${ }^{51}$, w całości jest życiem i pozostaje w nieustannym ruchu, jest czysty, prawy i bez skazy, ma wolną wolę, jest cnotliwy, nieśmiertelny i niezmienny i niewzruszenie trwa w stanie łaski, oddając się nieustannie służbie Bożej ${ }^{52}$. Zauważ jednak, że podana definicja czy raczej objaśnienie nie odnosi się do każdego anioła, to znaczy do demona, bowiem ten nie jest rozumny, prawy ani czysty, ani bez skazy, ani cnotliwy, ani w stanie łaski, lecz [odnosi się] do błogosławionych aniołów, o których będzie teraz w większości mowa. Prawdą jest bowiem, że owa definicja jest raczej pobożnym objaśnieniem błogosławionego anioła, nie zaś definicją właściwą, uczoną i teologiczną. Ponieważ jednak nie mamy tu zamiaru mówić szczegółowo, subtelnie i uczenie jak do wielkich duchownych, lecz do osób prostych i pobożnych, przyjmujemy owo pobożne objaśnienie natury anielskiej z należną czcią, bo zawiera w sobie samą prawdę.

\section{Rozdział III traktuje o tym, czy rzeczywiście istnieją anioły na świecie}

Prawdą jest, że byli tacy, którzy wątpili w istnienie istot, które zwie się aniołami, z tej przyczyny, że zwykle się nam nie objawiają. Im to odpowiadamy, że rzeczywiście istnieją anioły na świecie i są niezliczone, wedle tego, co mówi Raban w Super Genesim XII ${ }^{\mathbf{5 3}}$. [...] Dlatego ów wielki doktor Damascen, pisząc o Hierarchii anielskiej Dionizego ${ }^{54}$, mówi tak: prawda zawarta w Piśmie Świętym oraz znanym twierdzeniu wielkich filozofów antycznych i w ruchach nieb, a także pojawianiu się komet i różnych cudów, jakie często widujemy, które dzieją się wbrew wiedzy i ludzkiej zdolności

51 W oryginale katalońskim racional, choć Jan Damasceński posługuje się określeniem „myśląca” - intelectualis. Zgodnie z przyjętym przez siebie założeniem Eiximenis upraszcza scholastyczne rozważania dotyczące natury anioła i nie wprowadza rozróżnienia na istotę rozumną, czyli dochodzącą do prawdy przez wnioskowanie, i myślącą, pojmującą prawdę bezpośrednio i całościowo.

52 Por. „Anioł zatem jest istotą obdarzoną rozumem, nieustannie czynną, wolną, bezcielesną, oddaną służbie Boga, z daru łaski naturalnie nieśmiertelną”, Jan Damasceński, Wykład..., II, 3, s. 64. Eiximeniańska definicja została zaczerpnięta niemal dosłownie z Jana Damasceńskiego, ale ponieważ różni się nieznacznie od wersji znanej z przekładu Burgundia z Pizy, istnieje możliwość, że autor Księgi aniołów korzystał z tłumaczenia opracowanego przez Roberta Grosseteste’a, do którego to autora odwołuje się w rozdziałach XI i XII, choć ze wskazaniem na inne dzieło, to jest komentarz do Imion Boskich Pseudo-Dionizego. Dziękuję za to spostrzeżenie Gioacchinowi Curiellowi z Bishop Grosseteste University (Lincoln, Anglia). We wskazanym przez Eiximenisa miejscu Raban Maur nie wspomina o aniołach.

54 Chodzi o Wykład wiary prawdziwej, rozdział VII Światło, ogień i ciała świetlne: Słońce, Księżyc i gwiazdy: „Jesteśmy więc przekonani, że gwiazdy nie pozostają w żadnym związku przyczynowym z tym, co się gdziekolwiek dzieje, co powstaje albo ginie, lecz tylko najwyżej mogą zapowiadać zmiany atmosferyczne. A gdyby ktoś utrzymywał, że zapowiadają one także wojny, choć ich nie powodują, oraz że słońce, księżyc i gwiazdy mają wpływ na nasze temperamenty, nastroje i dyspozycje - odpowiadamy, że stany te mimo wszystko nie przekreślają naszej wolności, bo powinny podlegać rozumowi i pozostawać pod jego kontrolą i kierownictwem. Pojawiają się natomiast czasem komety, jako pewnego rodzaju znaki, zwiastujące śmierć królów. Nie należą one do gwiazd stworzonych na początku, lecz powstają z Boskiego rozkazu w określonym czasie, po czym się rozpadają”, J. Damasceński, Wykład..., II, 7, s. 79-80. 
przewidywania - zwłaszcza klęski poniesione w bitwach, nagłe wywyższenie lub upadek wielkich ludzi albo udaremnienie czy odmienienie ich celów i zamiarów, albo wspomożenie i przygotowanie straszliwych zdarzeń - ukazuje nam, że obecność i istnienie aniołów oraz ich wzniosła tajemnica i służba Boża są wewnątrz nas i między nami, bowiem Bóg wszystko, co chce nam uczynić, czyni przez tajemnicę i dzieło anielskie, wedle tego, co wykładają święci doktorzy ${ }^{55}$. Winniśmy przeto pamiętać, ile łaski i miłosierdzia Pan nam okazuje, pragnąc, byśmy byli prowadzeni i rządzeni z pomocą i przez nieustanne działanie świętych aniołów, tych pełnych chwały i cudownych duchów.

Z tych wszystkich powodów wynika, że zaprzeczanie istnieniu aniołów bierze się z wielkiego niedostatku wiary oraz nieznajomości Pisma Świętego, a także małego rozeznania w filozofii. Filozofowie uznali bowiem istnienie intelektów poruszających ciałami niebieskimi, wedle tego, co możemy znaleźć w ich pismach ${ }^{\mathbf{5 6}}$, a owe intelekty nazywamy w niniejszej księdze aniołami i uznajemy je za prawdziwe i najwyższe sługi naszego Pana Boga. Zaś racje i założenia przytoczone wyżej, a przeciwne [tej tezie] nic nie są warte, bo kiedy mówi ktoś, że anioły nie istnieją, gdyby miał rację, to nie istniałyby tak samo Bóg, raj, piekło ani czyściec na tym świecie, ponieważ żadna z tych rzeczy nie ukazuje się naszym zewnętrznym zmysłom. A przecież wszyscy wielcy teologowie mają tę pewność, że więcej jest rzeczy niewidzialnych niż widzialnych. Dlatego prawdą jest, że ich ${ }^{57}$ zdanie i rozumowanie nie jest nic warte.

\section{Rozdział IV, który naucza, że anioł jest substancją duchową i niecielesną}

Wiedz zatem i wierz niewzruszenie, że naprawdę istnieje anielska natura i niech starczy, co w poprzednim rozdziale zostało przytoczone przez owego doktora na dowód, że tak jest. A przyjąwszy takie założenie, zobaczymy, jaki jest anioł wedle definicji podanej wyżej, w drugim rozdziale, i tego, co [owa definicja] głosi. Otóż wspomniani doktorzy, a zwłaszcza Dionizy, [twierdzą], że anioł jest substancją duchową, nie zaś cielesną ${ }^{58}$. Tak podaje owa pobożna definicja wyżej przytoczona. A winniście jeszcze wiedzieć, że wedle tego, co pisze Laktancjusz ${ }^{59}$ w Homilii

55 Por. „Przybierają postać, jaką im wskaże Bóg, ich Pan, i w niej ukazują się ludziom, by im odsłaniać Boże tajemnice”, J. Damasceński, Wykład..., II, 3, s. 67.

56 Ponieważ Eiximenis nigdy nie odwołuje się do konkretnych autorów, zakładam, że jego znajomość filozofii starożytnej ma swoje źródło w lekturze scholastyków, między innymi św. Tomasza z Akwinu, z którego - jak zobaczymy - często korzysta, choć nigdy nie wskazuje wprost na Akwinatę jako źródło inspiracji.

57 Przeciwników tezy o istnieniu aniołów.

58 Pseudo-Dionizy Areopagita, Hierarchia niebiańska, IV, 2, s. 63-64; J. Damasceński, Wykład..., II, 3, s. 64.

59 Laktancjusz (ok. 250-ok. 330) - nauczyciel retoryki, pisarz i teolog, autor licznych traktatów apologetycznych i polemicznych oraz dzieła Divinarum institutionum libri VII, stanowiącego wykład religii i nauki chrześcijańskiej. 
o aniołach, tak bardzo jest duchowa natura anielska i tak daleka od cielesnej, że nie zajmuje miejsca, w którym przebywa, stając się przeszkodą dla innego ducha, ani nie posiada ciała, kiedy się komuś objawia ${ }^{\mathbf{6 0}}$. Przeciwnie, wszystkie duchy, ile ich jest, mogą przebywać razem w dowolnym miejscu. Tak jak się to dzieje w człowieku, w którego ciele znajduje się jego dusza w ten sposób, że cała jest obecna w całym ciele, a także w każdej jego części, a z nią najwyższy duch, który jest Bogiem. I tak samo jest we wszystkich rzeczach stworzonych, w których często przebywa dobry anioł, przynosząc wzniosłą inspirację, a czasem zły - przynosząc złe myśli, gdy znajdzie się w środku ${ }^{61}$. Z tej właśnie przyczyny mogłyby tu, w jednym miejscu przebywać wszystkie duchy stworzone, dobre i złe, bez żadnej trudności, bowiem nie są sobie nawzajem przeszkodą i nikt nie powinien się temu dziwić. Mówi ów doktor, że [dzieje się to] tak jak widzimy w naturze przebywające razem w jednym ludzkim ciele różnorakie esencje i materię, a także liczne formy substancjalne i akcydentalne i żadna nie jest przeszkodą dla drugiej, lecz przeciwnie, jedna drugą wspomaga w istnieniu i wymaga jej dla swego dobra, trwania, istnienia i działania. Zatem jeśli coś takiego widzimy w naturach cielesnych, tym bardziej prawdą jest, że mogą przebywać razem, nie stanowiąc dla siebie przeszkody, liczne natury i esencje duchowe, takie jak anioły i dusze. Dlatego prawdą jest to, co wyżej powiedziano, że wiele aniołów może przebywać razem, bowiem nie posiadają ciała zajmującego miejsce, jak człowiek albo kawałek drewna, albo kamień czy inne podobne ciało, które nie mogą przebywać razem z przyczyny swojej natury ${ }^{\mathbf{6 2}}$. Co jednak nie przeczy temu, że anioł jest obecny w miejscu, w którym jest obecny, a nie w innym miejscu, również ze względu na swoją naturę. Ponieważ z natury anioł nie może być wszędzie w tym samym czasie, tak jak jest Bóg, ani w wielu [miejscach] naraz, bowiem jego natura jest skończona i ograniczona do tego, by przebywać w jednym tylko miejscu ${ }^{63}$.

Wedle tego, co podaje Strabus w Super Genesim ${ }^{64}$, choć wiele aniołów może przebywać razem w tym samym miejscu, jednak w swej wzniosłej mądrości Pan, nasz Bóg, który je stworzył w niebie empirejskim, nie umieścił ich wszystkim razem

60 Eiximenis streszcza tu wywód zawarty w cz. I, z. 52, a. 1 Sumy teologicznej Tomasza z Akwinu.

61 Por. „Według Augustyna, dusza jest w każdej części ciała. Otóż złe duchy, aczkolwiek nie mogą owładnąć umysłów, to jednak niekiedy owładają ciałami; w ten sposób dusza i zły duch są równocześnie w tym samym miejscu", Tomasz z Akwinu, Suma teologiczna, t. 4: Bóg Stwórca (1. 44-49); Aniołowie (1. 50-58), przeł. i oprac. P. Bełch, London 1978, cz. I, z. 52, a. 3, s. 108. Mimo że opracowując treść rozdziału, Eiximenis korzystał również, jak się wydaje, z komentarzy do Zagadnienia 52 Sumy, to w kwestii tego, czy wiele duchów może przebywać jednocześnie w tym samym miejscu, z Akwinatą się nie zgadzał. Por. „Chociaż anioł nie znajduje się na sposób ciał w żadnym miejscu, które by go obejmowało, nadając mu postać i kształt, to jednak mówimy, że jest w jakimś miejscu obecnością właściwą duchowi”, J. Damasceński, Wykład..., I, 13, s. 56.

63 Por. „[Anioł] nie znajduje się wtedy gdzie indziej, lecz duchowo tam jest, gdzie i działa. Nie może bowiem działać jednocześnie w różnych miejscach, gdyż tylko Bogu właściwe jest działanie w tym samym czasie wszędzie”, J. Damasceński, Wykład..., I, 13, s. 56-57.

64 Walafrid Strabo (lub Walafridus Strabus; ok. 808-849) - poeta i egzegeta biblijny, uczeń Rabana Maura. Eiximenis przywołuje tu Glossa ordinaria super Genesim et Exodum (PL 113), tekst tradycyjnie przypisywany Strabusowi, autorstwa prawdopodobnie Anzelma z Laon (zm. 1117). Ponieważ przypisywane 
w jednym punkcie, ale rozsiał po całym niebie. A uczynił tak, by ozdobić nimi całe niebo, tak jak się zdobi piękną misę ze złota lub srebra, osadzając na niej płatki emalii i drogie kamienie. Tak samo anioły rozsiane w różnych miejscach i porządku służyły większemu pięknu i ukazywały najwznioślej wielką mądrość, potęgę i wspaniałość ich Stwórcy, naszego Pana Boga. I podaje jeszcze, że niebo empirejskie, które jest dla nas niepojętej wielkości, wypełniają owe błogosławione duchy ${ }^{65}$. Z tej przyczyny, mówi, rozważyć możesz, jak ogromna jest szczodrobliwość i moc Pana, który uczynił tak szlachetne stworzenia w takiej mnogości, tak wysoko je umieścił i tak zachwycająco uporządkował. I mówi on jeszcze, że nie powinien nikt powątpiewać w to, że często przebywają w nas dobre i złe anioły, jak o tym nieraz wspominali święci prorocy, a zwłaszcza Ezechiel. Bo gdy mówi, że anioł z nim rozmawiał, to znaczy, że anioł w nim przemawiał ${ }^{66}$. Potwierdza to potępiony w Paryżu artykuł, który głosi, że anioł może działać tylko tam, gdzie jest obecny ${ }^{67}$. Co jest błędem ${ }^{68}$, ponieważ prawdą jest, że zawsze gdy dobry lub zły anioł pobudza nas do czegoś przez serce lub będąc w nas samych, trzeba, by anioł w nas był. $Z$ tej przyczyny prawdziwa jest pierwsza część definicji anielskiej, która mówi, że anioł jest naturą duchową, nie zaś cielesną. Ponieważ prawdą jest, że między aniołem a człowiekiem zachodzi różnica, bowiem anioł jest natury duchowej, nie cielesnej, z której nic nie ma. Człowiek zaś jest natury złożonej: duchowej i cielesnej, to znaczy składa się z duszy i ciała.

\section{Rozdział V, który pokazuje, jaki jest duch anielski i że nie ma nic cielesnego, ale może przybrać i uformować ciało, w którym zamieszkuje}

Duchowa natura anioła jest tak wielka, że nie tylko sam w sobie jest bezcielesny, ale jeszcze nie jest powiązany z ciałem w sposób naturalny jak nasza dusza ${ }^{69}$. I prawdą jest to zarówno dla złego, jak i dobrego anioła. Zaś Ricardus podaje na dowód

Strabusowi przez Eixiemenisa zdania nie pojawiają się w Glossie, zakładam, że ich źródłem jest jakieś opracowanie powołujące się jedynie na Strabusa.

" «In principio [creavit]» etc. Coelum non visibile firmamentum, sed empyreum [...], quod statim repletum est angelis", W. Strabus, Glosa ordinaria..., 68C. Ten sam fragment również u Piotra Lombarda, Cztery księgi..., t. 1, ks. II, D. II, r. 4 (10), s. 338.

66 Kto przemawia do Ezechiela w wizjach opisanych w biblijnej Księdze Ezechiela, nie jest do końca jasne, choć dziś przyjmuje się, że Bóg.

67 Artykuł 204 z 219 tez potępionych przez biskupa Paryża Stefana Tempiera w 1277 roku. Skierowane przeciw arystotelizmowi potępienie zakazywało nauczania w nurcie awerroizmu łacińskiego, a także objęło niektóre z koncepcji Tomasza z Akwinu, jak tę dotyczącą obecności aniołów w miejscu. Por. Tomasz z Akwinu, Suma..., t. 4, cz. I, z. 52, a. 1.

68 Błędem jest potępienie artykułu, nie jego treść.

69 Uzasadnienie tezy podaje Tomasz z Akwinu, Suma..., t. 4, cz. I, z. 51, a. 1: Czy aniołowie maja ciała złączone z nimi w sposób naturalny, s. 100-101. Jeszcze Piotr Lombard uważał, że anioły posiadają 
prawdziwości [owej tezy], co czytamy u Mateusza rozdział IV: wielka mnogość diabłów mieściła się i przebywała w ciele opętanego, bo był w nim cały legion ${ }^{70}$, to jest sześćset sześćdziesiąt sześć ${ }^{71}$, co nie mogłoby dojść do skutku, gdyby wszystkie te demony miały ciała. Podobnie nic niewart jest argument przytaczany przez niektórych, że demony powinny mieć ciała, bo inaczej nie mogłyby być dręczone przez ogień piekielny ${ }^{72}$. Bowiem według świętych doktorów również czysty duch pozbawiony ciała może być okrutnie dręczony przez materialny ogień ${ }^{73}$, bo tak się podoba Bożej sprawiedliwości. I tak rzeczywiście jest dziś w piekle. Nie przecząc temu, winieneś jednak pamiętać, że zarówno anioł dobry, jak i zły może uformować ciało, które nam się zda ciałem ludzkim, choć nim nie jest ${ }^{74}$. Tak jak czytamy u Tobiasza, rozdział V, że to anioł Rafał towarzyszył synowi Tobiasza w długiej drodze, a jeszcze czytamy, że objawił się pod postacią pięknego młodzieńca gotowego do drogi. I ciała takie owe duchy formują, pragnąc się nam ukazać ku naszemu pożytkowi, nauce, wiedzy i pouczeniu, jak to czynią dobre anioły. Lub przeciwnie, aby nas oszukać lub inne zło uczynić, jak w przypadku demonów, których to rzeczy nie potrafiłyby tak zręcznie dokonać bez ciała, jak potrafią w ciele. Tak samo, jak widzimy w sztukach mechanicznych, w których rzemieślnicy bez właściwych swemu kunsztowi narzędzi nie mogliby odpowiednio pracować zgodnie ze sztuką, jak mogą, gdy posiadają narzędzia odpowiednie do wykonywanego dzieła.

jakiś rodzaj ciała, choć niematerialnego. Przekonanie, że anioł jest czystym duchem, ugruntowało się w myśli teologicznej dopiero w XIII wieku.

70 W Ewangelii wg św. Mateusza, Łukasza i Marka (Mt 8,28-34; Łk 8,26-39 i Mk 5,1-20) czytamy o uzdrowieniu opętanego i świniach, jednak tylko u Łukasza i Marka pojawia się określenie „legion” (podaję w przekładzie Biblii Tysiąclecia [wyd. 4, Poznań 2003], ponieważ u Wujka tłumaczenie brzmi „wojsko”): „I zapytał go: «Jak ci na imię?» Odpowiedział Mu: «Na imię mi 'Legion', bo nas jest wielu»” (Mk 5,9). Do tego fragmentu odwołuje się również Jan Damasceński: „Dlatego nie mają ani żadnej mocy, ani władzy nad kimkolwiek, wyjąwszy wypadek, gdy im Bóg na to pozwoli dla celów wyższych, jak [...] w zdarzeniu ze stadem wieprzów, o którym czytamy w Ewangelii”, J. Damasceński, Wykład..., II, 18, s. 69.

71 Skojarzenie z liczbą drugiej Bestii z Apokalipsy św. Jana: „Tu jest mądrość. Kto ma rozum, niech zrachuje liczbę bestii; albowiem liczba jest człowieka: a liczba jego sześćset sześćdziesiąt i sześć" (Ap 13,18).

72 Por. „Niektórzy to myślą, opierając się na słowach Augustyna, [że złym aniołom] owe ciała nikłe przemienione zostały w ciała gorsze i gęstsze, w których mogliby cierpieć od wyższego żywiołu, to jest od ognia”, P. Lombard, Cztery księgi..., t. 1, ks. II, D. VIII, r. 1 (43), s. 360-361.

73 Por. „Dlatego to zarówno diabłu i jego demonom, jak też wszystkim, którzy im ulegają, przygotowany jest «ogień niegasnący» i wieczna kara”. I dalej: „Wtedy diabeł i jego demony oraz jego człowiek, tj. Antychryst, a także bezbożni i grzesznicy będą wydani w ogień wieczny. Nie w ogień materialny, jak ten nasz, lecz taki, którego naturę zna tylko Bóg", J. Damasceński, Wykład..., II, 4, s. 69; IV, 27, s. 269. Pierwszy z cytatów może sugerować interpretację podaną przez Eiximenisa, lecz następny wyklucza ją zupełnie. Za materialnością piekielnego ognia opowiada się natomiast Piotr Lombard w czwartej księdze Sentencji, w dystynkcji XLIV, w której powołuje się na słowa św. Augustyna: „To piekło, które nazwane zostało jezioro ognia i siarki, będzie ogniem cielesnym, i będzie dręczyło ciała potępionych, ludzi i demonów, lecz rzetelne ludzi, a powietrzne demonów”, P. Lombard, Cztery księgi sentencji, t. 2, przeł. J. Wojtkowski, Olsztyn 2015, ks. IV, D. XLIV, r. 6 (256), s. 548.

74 Por. „Tak dalece nie ujętą mają postać, że kiedy na zlecenie Boga objawiają się sprawiedliwym, nie ukazują się im takimi, jakimi są, lecz w kształcie przybranym, dostrzegalnym dla oczu tych, którzy na nich patrzą", J. Damasceński, Wykład..., II, 18, s. 66. 
Zauważ jeszcze po wtóre, że ciała, które owe duchy formują, nie są w rzeczywistości ciałami ludzkimi, bowiem takie stworzyć może jedynie sam Bóg. Zaś człowiek nie może powiedzieć, że dlatego anioły nas oszukują, ukazując się jako ludzie, którymi nie są ${ }^{75}$. Tak jak Jezus Chrystus nie oszukuje uczniów, gdy idzie do zamku Emaus ${ }^{76}$ pod postacią pielgrzyma, nie przyznając się, że pielgrzymem nie jest ${ }^{77}$. Ani także Bóg nie oszukuje apostołów, którym posyła Ducha Świętego pod postacią ognia w dzień Pięćdziesiątnicy, nie wyjawiając, że Duch Święty nie jest ogniem ani gołębiem, chociaż ukazał się nad Jezusem Chrystusem pod postacią gołębia. Wystarczy jednak zbadać owe ciała, bowiem w rozumieniu Pana naszego, prawdziwego Boga, który jest źródłem wszelkiej prawdy, znaczą one rzeczy podobne do pewnych właściwości owych ciał ${ }^{78}$. Dlatego kiedy Duch Święty rozpłomienił apostołów w miłości, ukazał się w formie podobnej do ognia, który jest płomienisty. A ponieważ Jezus Chrystus jest czystą niewinnością bez grzechu, Duch Święty oznaczał Jego niewinność pod postacią gołębia, ptaka niewinnego ${ }^{79}$. Tak samo anioł, gdy chce coś dla nas zdziałać jak stworzenie racjonalne i szlachetne, przybiera ludzkie ciało, by działać z rozumem i rozwagą, które ma jak my ${ }^{80}$. Bowiem owo ciało jest narzędziem stworzenia rozumnego, to jest człowieka, którego Bóg umieścił ponad każdą inną cielesną i rozumną naturą.

\section{Rozdział VI, który pokazuje, w jaki sposób duchy anielskie formują ciała, w których zamieszkują i się objawiają}

Materię o tym, jak duch czyni takie ciało i co w nim robi, ujrzysz przez wybrane twierdzenia. Pierwsze twierdzenie jest takie, że bierze on porcję żywiołu powietrza i tak jak zimno zagęszcza wodę i ją utwardza, aż zmieni się w lód albo kryształ, tak przez pewną naturalną moc przed nami ukrytą [anioł] zagęszcza i ściska powietrze mniej więcej w taki sposób, w jaki owo powietrze chce uformować w kształt lub

75 Ten sam zarzut, a potem jego odparcie znajdują się u Tomasza z Akwinu, Suma..., t. 4, cz. I, z. 51, a. 3, s. 103.

76 Określenie Emaus jako zamku na podstawie katalońskiego oryginału - castell. Biblia Tysiąclecia tłumaczy w tym miejscu „wieś”, a Wujek „miasteczko”.

$77 \quad$ Łk 24,13-16.28-32.

78 Por. „Wcale nie występuje przeciw prawdzie to, że Pismo św. opisuje rzeczy duchowe za pomocą obrazów cielesno-zmysłowych; czyniąc bowiem tak, nie chce podsuwać myśli, że rzeczy duchowe są cielesno-zmysłowe, ale poprzez obrazy cielesno-zmysłowe drogą podobieństwa daje nam poznać właściwości rzeczy duchowych", Tomasz z Akwinu, Suma..., t. 4, cz. I, z. 51, a. 3, s. 104.

79 Dziki gołąb nazywany jest czystym ptakiem w Etymologiach Izydora z Sewilli (XII, c. 7, par. 61-62). Fizjologi i Aviarium. Średniowieczne traktaty o symbolice zwierząt, przeł. i oprac. S. Kobielus, Tyniec 2005, s. 72.

80 Por. „Aniołowie nie potrzebują przybranego ciała dla siebie samych, ale dla nas”, Tomasz z Akwinu, Suma..., t. 4, cz. I, z. 51, a. 2, s. 102. A także: „Podobnie wcale nie godzi w prawdziwość świętych aniołów to, że przybrane przez nich ciała ludziom wydają się być żyjące, chociaż takowymi nie są. Przywdziewają je bowiem tylko po to, by przez właściwości człowieka i czynności człowieka oznaczyć duchowe właściwości aniołów i ich duchowe czynności”, Tomasz z Akwinu, Suma..., t. 4, cz. I, z. 51, a. 3, s. 104. 
twardość, lub miękkość krwi lub ciała, lub kości, lub [w inne] właściwości. I części owe w taki sposób zmiękczone lub utwardzone łączy jedną z drugą, aż zdolne są ukazać formę ciała ludzkiego. Jednak z tego powodu, że ciało ludzkie ma w sobie rozliczne kolory, a kolory są dziełem natury, nie sztuki, trzeba, by powietrze, z którego formuje ciało, nie było czystym powietrzem, lecz dostatecznie złożonym i zmieszanym z innymi delikatnymi kolorami, które miałyby różne barwy. Tak jak widzimy, że chmura w różnych miejscach ma różne barwy, bo w jednym miejscu jest biała, w innym czarna, w innym czerwona, a w jeszcze innym ma zmieszane kolory, tak anioł, chcąc uformować ciało, musi mieszać różne jasne barwy, podobne naturze powietrza i w różnych kolorach ${ }^{81}$. Bo dzięki owym mieszankom ciało w ten sposób uformowane zachowa barwy stosowne dla ludzkiego ciała zgodnie z tym, czy chciał będzie ukazać ciało piękne czy brzydkie lub w takim czy innym typie. Bo dziecko ma barwę twarzy odmienną od starca, inną ma mężczyzna i inną niewiasta, i odmienną ma człek pokutujący od człeka grubego i tłustego. I to samo tyczy się innych cech ludzkich, które anioł chciałby ukazać.

Drugie twierdzenie jest takie, że intencją, przez którą anioł formuje ciało w sposób, jak już omówiono, jest się nam ukazać i zdziałać w nas to, co chce, a nawet zamieszkać w kimś oraz objawić się jako stworzenie rozumne. A ponieważ wszystko to mógłby uczynić, poruszając jedynie ciałem tak stworzonym, oczywistym jest, że nie ma konieczności, by anioł dawał życie owemu ciału ani by owo ciało żyło albo wykonywało czynności życia.

\section{Rozdział VII, który naucza, że owe duchy w ciałach zamknięte nie jedzą ani nie piją ${ }^{82}$}

Rzekniesz, że niezliczone świadectwa stoją w sprzeczności z powyższym drugim twierdzeniem, wedle którego anioł nadaje czynności życia ciału, jakie przyjmuje. Po pierwsze czytamy w Księdze Rodzaju, rozdział XVIII, że anioły, które ugościł Abraham, jadły i piły wraz z nim ${ }^{83}$. I anioł, który szedł z Tobiaszem, jadł i pił wraz z nim ${ }^{84}$, inaczej Tobiasz rozpoznałby, że to nie człowiek z nim podróżuje. Podobnych świadectw znajdziesz bez liku w dawnych żywotach świętych ojców. Po drugie

81 Por. „Jakkolwiek powietrze w stanie rozrzedzonym nie otrzymuje kształtów ani barw, w stanie jednak zgęszczonym może nabywać kształty i odbijać barwy - świadczą o tym chmury. Tak to właśnie aniołowie biorą sobie ciała z powietrza: mocą Bożą zgęszczają je jak i ile trzeba do utworzenia ciała, które chcą przybrać", Tomasz z Akwinu, Suma..., t. 4, cz. I, z. 51, a. 2, s. 103.

82 Rozdział przedstawia argumenty zawarte w Sumie Tomasza z Akwinu, t. 4, cz. I, z. 51, a. 3: Czy aniołowie w przybranych ciałach wykonują czynności życia, s. 103-105.

83 Rdz 18,1-15. Do Księgi Rodzaju w z. 51, a. 3 Tomasz z Akwinu odwołuje się dwa razy, w punkcie 5 i w odpowiedzi na niego, Tomasz z Akwinu, Suma..., t. 4, cz. I, z. 51, a. 3, s. 103, 105.

$84 \mathrm{~Tb} 6,5 ; 7,14 ; 8,1 ; 12,19$. Ten sam przykład podaje również Tomasz z Akwinu w odpowiedzi na punkt 5: „[...] mówił anioł do Tobiasza: «Gdym był z wami [...] wydawało się [...] żem z wami jadł i pił; ale ja 
powyższe twierdzenie zdaje się fałszywe, ponieważ zdarza się często, że diabeł przybiera kształt mężczyzny lub niewiasty i pokłada się z niewiastą albo, pod postacią niewiasty, z mężczyzną. Tak jak u św. Augustyna, który mówi często o inkubach i sukubach ${ }^{85}$. A jeszcze mocniejszy argument jest taki: często zdarzało się, że diabeł, pokładając się z niewiastą, płodził ludzi, jak to czytamy zwłaszcza o Merlinie ${ }^{\mathbf{8 6}}$. I wielu powiada, że w taki sposób zostanie spłodzony Antychryst. Zatem ponieważ jedzenie i płodzenie potomstwa jest dziełem naturalnego życia i rzeczy takowe dzieją się za sprawą ciał przyjętych przez złe duchy, zdaje się, że owe anioły dają prawdziwe życie owym ciałom. A jeśli diabły mają dość mocy, by dać życie, stąd wniosek, że tym bardziej mogą to czynić dobre [anioły]. Z tego wniosek, że nie można zaprzeczyć, by duchy dawały życie ciałom przez siebie uformowanym, kierowanym i przybranym.

Na pierwszy z argumentów odpowiadam, że choć wspomniane święte anioły przyjmowały pokarm i go spożywały, przekształcały go w inną materię poza sobą i potajemnie. Bowiem owa materia nie przekształcała się w ciała, które przybierały, jak to się dzieje w nas z tym, co spożywamy. Stąd wniosek, że przyjmowanie pokarmów nie było prawdziwym jedzeniem ani prawdziwym piciem ${ }^{87}$, lecz przyjmowaniem pokarmu i konsumowaniem go nie za sprawą naturalnego ciepła, jak to się w nas dzieje, lecz raczej przez sprytną sztukę ${ }^{\mathbf{8 8}}$. Tak jak w odmienny sposób konsumuje potrawę garnek na ogniu, a w odmienny nasz żołądek, ponieważ pierwsza z czynności jest nienaturalna, zaś druga naturalna. Tak samo jest w tym przypadku, kiedy pokarm konsumuje anioł, który go spożywa sztuką i sprytem, choć w nas dokonuje się to przez naturalne ciepło i drogą naturalną. Dlatego prawdą jest, że spożywanie przez anioły pokarmów i ich konsumpcja nie jest czynnością życia, lecz dzieje się za sprawą sztuki i wiedzy.

Na drugi argument, że diabeł może spłodzić potomstwo i w rzeczy samej tego dokonał, odpowiem, że po prawdzie diabeł nie może dokonać podobnej rzeczy. Chociaż mógłby sprytem przygotować materię potrzebną do ludzkiego zapłodnienia, jednak człek stworzony w ten sposób nie jest ani stworzony, ani spłodzony naturalnie, bowiem pochodzi od diabła. Zaś diabeł nie dysponuje materią zapładniającą

pokarmu niewidzialnego i napoju, który od ludzi oglądan być nie może, używam»”, Tomasz z Akwinu, Suma..., t. 4, cz. I, z. 51, a. 3, s. 105.

85 Por. „Augustyn opowiada: «Niejeden utrzymuje, że sam doświadczył lub słyszał od tych, co sami doświadczyli, że sylwany i fauny, których lud pospolicie zwie inkuby-zmory, naprzykrzali się kobietom, natarczywie od nich żądając, no i obcując z nimi cieleśnie»”, Tomasz z Akwinu, Suma..., t. 4, cz. I, z. 51, a. 3, s. 105 :

86 Diabelskie pochodzenie przypisał Merlinowi Robert de Boron w powstałym na początku XIII wieku poemacie Merlin.

87 Por. „Natomiast pokarm brany przez aniołów ani nie obracał się w ciało przybrane, ani też owo ciało nie było takiej natury, żeby pokarm mógł się w nie obrócić. Nie było to więc prawdziwe jedzenie, a tylko obrazujące spożywanie duchowe, o jakim mówił anioł do Tobiasza [...]”, Tomasz z Akwinu, Suma..., t. 4, cz. I, z. 51, a. 3, s. 105.

88 Kat. art; tu w znaczeniu umiejętność, tak jak w określeniu artes mechanicae, to jest sztuki manualne, czyli rzemiosło. 
z natury ani przez czynności życia, lecz dzięki sprytowi albo sztuce i swojej wiedzy w tej kwestii. Bowiem mówią święci doktorzy, że diabeł w postaci niewiasty przyjmuje od mężczyzny nasienie, które następnie przekazuje i przenosi niewieście, przyjmując formę mężczyzny i pokładając się z niewiastą, która ową materię przyjmuje w miejsce przeznaczone do spłodzenia człowieka i gdy znajdzie się tam owa materia, niewiasta przygotowuje ją w sposób naturalny na przyjęcie życia i by stała się człowiekiem, tak jakby zapłodnił ją mężczyzna zwyczajną koleją rzeczy. Dlatego prawdą jest, że diabeł tu nie współdziała ani nie działa naturalnie, stąd wniosek, że nie wykonuje czynności naturalnego życia, ale sprytnej sztuki ${ }^{89}$. O tej kwestii nie chcę jednak więcej mówić, bowiem jest brzydka i nikczemna i nigdy bym o niej nie powiedział, gdyby temat tego nie wymagał koniecznie, bo widziałem, że św. Augustyn i inni święci doktorzy obszernie go omówilii ${ }^{\mathbf{9 0}}$, rozważając podobne kwestie i rozwiązując ową trudność. I zauważ, że duch nie tylko nie może dokonać owych dzieł i czynności życia w ciele, lecz jeszcze nie może ani czuć niczego, ani postrzegać przez moce cielesne, ani przez członki ciała. Zatem chociaż duch porusza okiem w ciele, to przez nie nie widzi ani nie słyszy uchem, ani nie czuje żadnym z członków ciała. Z tej przyczyny, że nie jest formą ani naturalnym owocem ciała ${ }^{91}$, lecz tylko jego poruszycielem ${ }^{92}$ i z własnej woli zarządcą i po prawdzie oko jego nie jest prawdziwym okiem ani ucho uchem i tak samo inne członki ${ }^{93}$. Zaś dzieje się tak z tej przyczyny, która została już przedstawiona: bowiem owe części ciała nie zostały uformowane w sposób naturalny, jakiego członki ciała wymagają. A choć mogłyby zostać prawdziwie nazwane okiem lub uchem czy innymi członkami ludzkiego ciała, to jedynie posiadają ich wygląd. I nie przecząc temu, duch może bez żadnej przeszkody wejść i przeniknąć przez dowolne ciało, co leży w jego mocy i naturze. Bowiem żadne ciało nie może być mu przeszkodą, gdyż tak samo i doskonalej niż

89 Por. „Jeżeli jednak są tacy ludzie, którzy niekiedy ponoć rodzą się z obcowania z demonami, to nie dzieje się to $\mathrm{z}$ nasienia pochodzącego od demonów albo wydanego przez ciało przybrane, lecz z nasienia zabranego do tego celu jakiemuś człowiekowi przez demona; jako że ten sam demon służy za partnerkę dla mężczyzny, a za partnera dla kobiety; zresztą, zdaniem Augustyna, demony biorą i nasiona innych rzeczy, by posłużyć się nimi do zrodzenia tego czy owego. Aliści tak zrodzony człowiek nie jest synem demona, lecz synem tego człowieka, od którego wzięto nasienie”, Tomasz z Akwinu, Suma..., t. 4, cz. I, z. 51, a. 3, s. 105.

$90 \quad$ Na podstawie wskazanych wyżej podobieństw do tekstu Sumy teologicznej można przypuszczać, że Eiximenis ma w tym miejscu na myśli Tomasza z Akwinu, który jest też dla niego źródłem wiedzy na temat poglądów św. Augustyna dotyczących „czynności życia” wykonywanych przez anioły.

91 W tym sensie, że nie powstał w sposób naturalny z ciała, nie został spłodzony i urodzony.

92 Por. „Ale aniołowie nie poruszają w taki sposób ciał przybranych, bo nie są ich formami. Jednakże aniołowie poruszają się pośrednio - przez przypadłość, gdy porusza się przybrane ciało; są bowiem w nim tak, jak poruszyciel jest w rzeczy poruszalnej”, Tomasz z Akwinu, Suma..., t. 4, cz. I, z. 51, a. 3, s. 104.

93 Por. „Bynajmniej więc nie należy mówić, że aniołowie czują za pomocą narządów ciał przybranych. [...] Nie są bowiem kształtowane po to, by przez nie czuć, ale - jak uczy Dionizy - zadaniem tychże narządów jest pokazać duchowe zdolności aniołów”, Tomasz z Akwinu, Suma..., t. 4, cz. I, z. 51, a. 3, s. 104. 
światło słońca, które wchodzi w głąb powietrza bez żadnej przeszkody i tam zostaje, tak samo każdy duch może wejść i zamieszkać wewnątrz dowolnego ciała, jakiego zechce. Z wszystkich tych rzeczy wynika, że prawdziwa jest pierwsza część definicji anioła, która mówi, że anioł jest substancją duchową, nie zaś cielesną.

\section{Rozdział IX, który naucza, że duch ów jest cały życiem i siłą we wszystkich swych działaniach}

Powróciwszy zatem do owej definicji, wykłada się tutaj, że bez wątpienia anioł jest w sobie życiem, a zważ, że ze wszystkich rzeczy żywych nie wszystkie są w sobie życiem. Jak na przykład człowiek albo zwierzę nie jest całe w sobie życiem, bo żyje tylko dzięki swej duszy ${ }^{94}$, która jest jego częścią i nie jest nim w całości, bo jest jeno częścią. Że w taki sposób każde zwierzę żyje, dowodzi tego, że gdy dusza opuszcza jego ciało, z powodu [braku] duszy żyć dalej nie może i ciało umiera. Prawdą jest zatem, że ciało żyje dzięki duszy i żadne zwierzę nie jest całe życiem i że jedynie dusza jest życiem zwierzęcia. Natomiast anioł taki nie jest, bowiem jest on cały życiem w sobie samym, w każdej części jednakowo jest cały życiem i cały pojmuje, postrzega, widzi i słyszy przez siebie samego. Dlatego nie potrzebuje oczu, by widzieć, ani uszu, by słyszeć. Nie ma też rąk, by dotykać, zmysłu dotyku, by czuć, głowy, by pojmować, ani też stóp, by chodzić. Bowiem cały jest niczym oko, cały jest czuciem i słuchem, i myślą, bez udziału jakiejkolwiek cielesności. I tak samo z wszystkimi innymi czynnościami należącymi do życia. Z tej to przyczyny anioł nie potrzebuje organów ani instrumentów cielesnych, by widzieć, słyszeć lub czuć, tak jak człowiek, któremu trzeba oczu, by widzieć, i specjalnych organów, by słyszeć, i tak samo z pozostałymi zmysłami. Dlatego kiedy organy i naturalne instrumenty są uszkodzone, człowiek nie może niczego zobaczyć ani usłyszeć, ani wykonywać czynności życia związanych z uszkodzonym instrumentem. Wedle tego, co podaje autor De spiritu et anima ${ }^{\mathbf{9 5}}$, cnota połączona jest silniejsza niż rozproszona ${ }^{\mathbf{9 6}}$. Z tej przyczyny - jako że cnota anielska jest połączona w całość i w relacji z całym aniołem we wszystkim, co czyni - wszystkie cnoty i możności anielskie posiadają tak wielką siłę i skuteczność, że w tym życiu nasz rozum nie jest w stanie pojąć tego w pełni.

94 Por. „Duch jest, który ożywia, ciało nic nie pomaga” (J 6,63). Również Tomasz z Akwinu, Suma teologiczna, t. 6: Człowiek. Cz. 1, 1. 75-84, przeł. i oprac. P. Bełch, London 1980, cz. I, z. 75, a. 1, s. 7-9.

95 Traktat przypisywano błędnie św. Augustynowi, choć jego autorem był prawdopodobnie Alcher z Clairvaux, cysterski mnich przebywający w opactwie w Clairvaux za czasów opata Geoffreya z Auxerre (1162-1165). Por. J. Martínez Porcell, Introducción y traducción del De Spiritu et Anima, un opúsculo inédito atribuido a Alcher de Clairvaux, „Espíritu” 67 (2018), núm. 155, s. 11-58; C. Mews, Debating the Authority of Pseudo-Augustine's “De spiritu et anima”, „Przegląd Tomistyczny” 24 (2018), s. 321-348.

96 Przypisywana Arystotelesowi sentencja „virtus unita fortior est se ipsa dispersa” przewija się przez całe, nie tylko teologiczne, piśmiennictwo średniowieczne w różnych wariantach, niemniej jednak w przywołanym przez Eiximenisa traktacie De spiritu et anima nie występuje. 
A że naturalna cnota i siła aniołów jest taka, jak powiedziano, możesz zobaczyć, jeśli przyjrzysz się anielskim dziełom pochodzącym z ich wielkiej siły. Przyjrzyj się zatem najpierw, jaką siłę mają anioły. Bowiem według świętych i filozofów nieba i ciała niebieskie są nieustannie poruszane przez anioły, zobacz więc, jak wielka jest cnota każdego z aniołów poruszającego każdym z ruchomych nieb, bo w przeciągu dwudziestu czterech godzin obracają wszystkie nieba od początku do końca, zakreślając perfekcyjne koło w swym ruchu okrężnym ${ }^{97}$. Pomyśl jeszcze, ile siły wymaga takie dzieło, kiedy w jednej niemal chwili anioł wznosi się z ziemi do nieba albo sprowadza $\mathrm{z}$ nieba na ziemię, albo przenosi z zachodu na wschód ${ }^{\mathbf{9 8}}$, albo gdy nagle niszczy wielką górę lub przestawia ją z jednego miejsca w inne. Pomyśl jeszcze, ile życia i naturalnej cnoty ma anioł w swej mocy, bowiem nigdy nie zapomina tego, co raz ujrzał, pojął lub poznał, a nadto widzi z jednego końca świata, co się dzieje na drugim, i nie przeszkadzają mu w tym ciemności ani ziemia pomiędzy [nim a tym, na co patrzy], ani inne rzeczy, które nam przeszkadzają ${ }^{99}$. Anioł widzi i słyszy tak samo z jednej strony, jak i z innej, nie tak, jak my, ale raczej jak światło, które rozdziela się jednakowo we wszystkie miejsca, tak też on widzi, słyszy, pojmuje i czuje wszędzie, tak na dole, jak i w górze, tak tu, jak i tam, bez żadnej trudności. I dzięki tej samej cnocie jest tak bystry i przenikliwy w pojmowaniu, że w stworzeniach i dziełach Bożych łatwo poznaje, że Bóg jest ich stwórcą, opiekunem i władcą; posiada całą wiedzę i zna wszystkie sztuki, a także wszelką rzecz przed nim odkrytą niezależnie od miejsca i czasu ${ }^{\mathbf{1 0 0}}$; pojmuje argumenty i sprawy mu przedstawione, a także widzi jasno wnioski pochodzące z różnych założeń i różnych sposobów [rozumowania] bez mitrężenia czasu ${ }^{\mathbf{1 0 1}}$. Prawdą jest też, że sam z siebie nie może poznać

97 O poruszaniu przez anioły ciał niebieskich pisze Tomasz z Akwinu w kilku miejscach Sumy teologicznej: „ciała bowiem niebieskie nie opuszczają całkowicie miejsca; również i duch poruszający okrąg (orbis) nie ma wyznaczonego miejsca związanego z jakąś określoną częścią substancji okręgu [...]; ale - jak uczy Filozof - ma tylko wyznaczone jedno miejsce czy położenie (situm), boć siła poruszająca zawsze jest na Wschodzie”, t. 4, cz. I, z. 51, a. 3, s. 105; „Nie musi też anioł - o ile jakiś porusza niebo - być wszędzie; po pierwsze dlatego, że jego siła przykłada się tylko do tego, co jest najpierw przezeń poruszane; owo wszczęcie ruchu nieba dokonuje się w jednej części nieba, mianowicie w części wschodniej. Tu powód, czemu to Filozof przyznał części wschodniej siłę poruszyciela niebios; po drugie, bo $\mathrm{u}$ filozofów nie spotykamy się z twierdzeniem, że jedno jestestwo oddzielone porusza bezpośrednio wszystkie okręgi”, t. 4, cz. I, z. 52, a. 2, s. 107-108.

98 Sposobowi, w jaki anioły się poruszają, Tomasz z Akwinu poświęcił z. 53, a. 1-3 Sumy: „Stąd też ruch lokalny anioła nie musi być współmierny z miejscem [...], jest ruchem nieciągłym”, t. 4, cz. I, z. 53, a. 1, s. 110; „A ta zaleta, mianowicie poruszać się z krańca na kraniec, nie zawadzając o miejsce pośrednie, może być przyznana aniołowi, ale nie ciału”, t. 4, cz. I, z. 53, a. 2, s. 113; „i tak anioł może w jednym momencie być w jednym miejscu, a w drugim momencie w innym miejscu - bez zaistnienia jakiegoś pośredniego celu”, t. 4, cz. I, z. 53, a. 3, s. 115.

Por. „dla poznania anioła jest obojętne, czy rzecz jest blisko czy daleko co do miejsca”, Tomasz z Akwinu, Suma..., t. 4, cz. I, z. 55, a. 2, s. 125.

We fragmencie poświęconym zdolnościom poznawczym aniołów Eiximenis streszcza z. 55 z cz. I Sumy: Środek, przez który odbywa się poznanie anielskie, Tomasz z Akwinu, Suma..., t. 4, s. 122-127.

101 Por. „Gdyby zaś w samym poznawaniu zasady sobie już znanej od razu widziała [myśl ludzka] jako sobie znane wszystkie wynikające zeń wnioski - co wtedy? Wtedy nie byłoby miejsca na rozumowanie; 
naszych myśli ani zgłębić naszego sumienia ${ }^{\mathbf{1 0 2}}$, jeśli nie zostały mu objawione przez najwyższą cnotę albo sam się nie domyśli przez wskazówki lub znaki przez człowieka na zewnątrz okazywane ${ }^{\mathbf{1 0 3}}$. Tak jak człek szalony okazuje na zewnątrz przez wyraźne znaki swoje szaleństwo, zaś człek pożądliwy okazuje wyraźnymi znakami i zewnętrznymi poruszeniami, co w sercu swym skrywa. Powodem, dla którego anioł nie zna tych spraw, jest że Pan nasz Bóg je przed nim ukrył, tak jak tajemnice świata. Bowiem jak podaje Pismo Święte, Jego mądrość i najwyższa wzniosłość wie, dlaczego tak i dlaczego nie i dopiero w czas sądu ostatecznego i w raju - wedle słów św. Pawła - objawi tyle, ile zechce w swej nieskończonej wzniosłości ${ }^{104}$. Dlatego, przez kwestie wyżej podane, prawdą jest, że anioł jest cały życiem i pełen siły we wszystkich działaniach wewnątrz siebie i poza sobą.

\section{Rozdział XIV, który naucza, że natura anielska została stworzona przez Boga}

Idąc dalej wedle porządku w onej materii, trzeba nam zobaczyć, jak natura anielska została umieszczona w świecie, ponieważ rzekliśmy, że rzeczywiście istnieje. Naucza o tym św. Augustyn w Super Genesim, gdzie mówi, że kiedy Bóg rzekł: „Fiat lux”105, to przez owe słowa winniśmy rozumieć, że stworzył naturę anielską, którą należy pojmować jako światło ${ }^{\mathbf{1 0 6}}$. Ponieważ tak jak zgodnie ze sztuką perspektywy światło jest najszlachetniejszą i najwyższą właściwością cielesną, jaka tylko istnieje, tak też natura anielska jest najwyższą naturą, jaką tylko Bóg stworzył. Z tej przyczyny trzeba uznać, że została stworzona na początku świata. I podaje Strabus w Super Genesim,

i to właśnie zachodzi u aniołów; oni bowiem w tym, co w sposób naturalny jako pierwsze poznawają, od razu widzą wszystko, cokolwiek można w tym poznać”, Tomasz z Akwinu, Suma..., t. 4, cz. I, z. 58, a. 3, s. 144-145.

Por. „aniołowie nie poznawają skrytości serc”, Tomasz z Akwinu, Suma..., t. 4, cz. I, z. 57, a. 4, s. 138. Por. „można poznawać skrytości serca [...] w swoim skutku czy przejawach; w ten sposób może je poznawać zarówno anioł, jak i człowiek; a im bardziej maskowane są owe przejawy tym wnikliwszego domagają się poznawcy”, Tomasz z Akwinu, Suma..., t. 4, cz. I, z. 57, a. 4, s. 138.

Por. „A więc aniołowie nie znają tajemnic łaski. [...] Otóż dzięki temu widzeniu poznawają tajemnice łaski; wszelako nie wszystkie i nie wszyscy jednakowo, ale według tego, jak Bóg zechciał im je objawić stosownie do słów św. Pawła: «Nam zaś objawił to Bóg przez Ducha»”, Tomasz z Akwinu, Suma..., t. 4, cz. I, z. 57, a. 5, s. 140 za: 1 Kor 2,10.

„I rzekł Bóg: Niechaj się stanie światłość: i stała się światłość” (Rdz 1,3).

Por. „[...] posługują się świadectwem Augustyna, który w Super Genesim mówi, że natura anielska najpierw bezpostaciowo stworzona i nazwana niebem, potem upostaciowana i nazwana światłem [...]. Dlatego [...] potem dodane [jest]: «I rzekł Bóg: Niech się stanie światłość!»”, P. Lombard, Cztery księgi..., t. 1, ks. II, D. III, r. 4 (16), s. 343. „Augustyn wyjaśnia, że aniołowie bynajmniej nie są pominięci w opisie owego pierwszego stworzenia rzeczy, tylko że oznaczono ich nazwą 'niebo' lub także 'światło", Tomasz z Akwinu, Suma teologiczna, t. 5: Aniołowie (część druga); Świat widzialny (1. 59-64; 65-74), przeł. i oprac. P. Bełch, London 1979, cz. I, z. 61, a. 1, s. 18. 
że Pan nasz Bóg stworzył na początku świata cztery rzeczy, to jest: niebo empirejskie, czas, pierwotną materię, z której powołał inne rzeczy, oraz, prócz owych trzech, stworzył jeszcze naturę anielską ${ }^{107}$, dzięki czemu anioły przewyższają w godności ludzi. Bowiem ludzie powstają w wyniku naturalnego zapłodnienia pomieszanego z wielką głupotą i nędzą. Tymczasem natura anielska już w stworzeniu została uchroniona przed wszelką ociężałością myśli i przez Boże rozkazanie stworzona. Dlatego chwali dobrego Pana za tę wielką dobroć, wołając do Boga w raju: „Scito quoniam Dominus ipse fecit nos”, co oznacza, aby każdy zrozumiał: wiedz, że Bóg nasz Pan jest prawdziwym Bogiem i on jest Tym, który nas stworzył, bo nie zostaliśmy poczęci tak jak ludzie drogą naturalną ${ }^{\mathbf{1 0 8}}$. Z tego wynika, że prawdą jest, że anioły zostały stworzone i w ten sposób się pojawiły [na świecie].

\section{Rozdział XVI, który mówi o liczbie aniołów}

Wątpią niektórzy, czy można poznać liczbę, w jakiej zostały stworzone [anioły], i zda się, że wątpił w to Hiob, mówiąc w rozdziale XXVI: „Numquid numerus est militum eius"109, co znaczy, że nie da się podać liczby Jego rycerzy, tylu ich jest, oraz to, co podaje glosa Hajmona ${ }^{\mathbf{1 1 0}}$, że są niezliczone, co z kolei oznacza, że ich liczba przekracza nasze pojmowanie. I tak należy rozumieć słowa z Psalmu XXXIX: „Multiplicari sunt super numerum"111, co oznacza, że zostały pomnożone do tak wielkiej liczby, że nie starczyło wiedzy, by ją pojąć. Wszystkie te słowa mają charakter tropiczny i są zabarwione retoryką, to jest zabiegiem zwanym tropus. Jednym z jego rodzajów jest hiperbola, co znaczy mówić z przesadą, czyli kiedy człowiek twierdzi, że kocha kogoś nad życie albo że nie zrobiłby tego czy owego nawet w zamian za wielkie królestwo, czy inne podobne rzeczy. W związku z tym trzeba, byś wiedział, że na temat liczby aniołów różni doktorzy różnie sądzili. Bo jedni mówią, że dobrych aniołów jest tyle, ilu będzie zbawionych ludzi ${ }^{112}$. Inni, że tyle, ilu będzie zbawionych i potępionych.

107 Być może na podstawie jakiejś zepsutej lekcji oryginału: „Proinde duas res fecit Deus ante omne tempus, angelicam creaturam et materiam informem”, W. Strabus, Glosa ordinaria..., 69B.

108 Eiximenis przywołuje tu Psalm 100(99),3, lecz zarówno sam cytat, jak i jego tłumaczenie traktuje dość swobodnie, por. „Scitote quoniam Dominus ipse est Deus ipse fecit nos et non ipsi nos populus eius et oves pascuae eius” - „Wiedzcie, że Pan jest Bogiem: On sam nas stworzył, my Jego własnością, jesteśmy Jego ludem, owcami Jego pastwiska”. „Numquid est numerus militum eius” - „Izali jest liczba żołnierzów jego?” (Hi 25,3).

Haimo (Aimon) z Auxerre (zm. ok. 865-875) - benedyktyn z opactwa Saint-Germain d'Auxerre, autor licznych komentarzy do Biblii.

1 Por. „Wieleś uczyniłeś ty, Panie, Boże mój, cudów twoich: a w myślach twoich nie jest, ktoby był podobien tobie: opowiadałem i mówiłem, rozmnożyli się nad liczbę" (Ps 40(39),6). dzaju ludzkiego, ilu tam udało się aniołom pozostać»”, P. Lombard, Cztery księgi..., t. 1, ks. II, D. IX, r. 7 (53), s. 369. 
A jeszcze inni, że jest bez porównania więcej, niż będzie zbawionych i potępionych razem. Bowiem mówi Strabus, że [anioły] całe niebo empirejskie wypełniły, gdy [Bóg] je stworzył, co jest prawdą ${ }^{113}$. Ale mówi też św. Anzelm w różnych traktatach, że nie można tego wiedzieć na pewno, zgodnie ze słowami Pisma Świętego albo świętego Kościoła, który w jednej z kolekt do mszy mówi tak: „Deus, cui soli cognitus est numerus electorum in superna felicitate locandus"114, co oznacza, że tylko Bóg zna liczbę zbawionych. A jeśli powiesz, że Mojżesz rzekł w Księdze Powtórzonego Prawa, rozdział XXXII: „Constituit terminos populorum iuxta numerum filiorum Israel”"115, po których to słowach doktorzy twierdzą, że Bóg pragnie, by liczba aniołów była równa liczbie zbawionych, to jest wybranych, odpowiedzą na to inni [doktorzy], jak św. Hieronim, że ów komentarz czy glosa nie ma uzasadnienia w Piśmie Świętym, które kazałoby w nią wierzyć. Kto jednak w nią wierzy, nie grzeszy, bo nie odrzuca Pisma Świętego ani niczego, co jest katolickie.

Jednak co się tyczy glos świętych autorów do słów św. Jana, który w Apokalipsie, rozdział XII, mówi, że smok zrzuci trzecią część gwiazd ${ }^{\mathbf{1 1 6}}$, to powszechnie objaśnia się te słowa jako upadek złych aniołów, kiedy to - jak mówią - upadnie trzecia część stworzonych przez Boga aniołów ${ }^{117}$. Tą drogą dochodzimy do stwierdzenia, że anioły występują w jakiejś liczbie, bowiem rzecz nieskończona nie może się dzielić na części. Zatem jeśli trzecia część upadnie, pozostałe dwie trzecie mają jakąś liczbę, czyli nie ma ich nieskończenie wiele. Lecz liczby owej w tym życiu nie znamy.

\section{Rozdział XVII, który podaje te imiona aniołów, o których wiemy}

Orozjusz w liście posłanym do Fabrycja patriarchy ${ }^{\mathbf{1 1 8}}$ rozważa kwestię, czy znane są imiona aniołów, i mówi, że nie ma wątpliwości co do tego, że Pan nasz Bóg nadał każdemu własne imię wedle jego właściwości. Dowodzą tego słowa Dawida w psalmie: "Qui numerat multitudinen stellarum et omnibus eis nomina vocat"119, co znaczy, że Pan nasz Bóg jest Tym, który nazwał mnogość swych aniołów, czyli gwiazd na niebie, i wszystkie je nazwał ich własnymi imionami. Lecz z owych świętych imion dotarły do nas tylko trzy. Pierwsze to Michał, co się tłumaczy „Któż jest prawdziwym Bogiem”, i jest on z porządku Zwierzchności, o którym powiemy obszernie

113 Por. przypis 64.

114 „Boże, tylko Tobie znana jest liczba wybranych, którzy się znajdą w szczęśliwości niebieskiej”. Zdanie należy do oratio super oblata (secreta) mszy za żywych i zmarłych. „założył granice narodów, według liczby synów Izraelskich” (Pwt 32,8). Por. „oto smok wielki rydzy [...] A ogon jego ciągnął trzecią część gwiazd niebieskich” (Ap 12,3-4). Por. „Bo, jak Jan mówi w Apokalipsie, smok, spadający z nieba, ciągnie trzecią część gwiazd niebieskich; ponieważ ów Lucyfer, większy od innych, nie spadł sam, lecz wielu innych z nim, którzy zgodzili się z nim w złości”, P. Lombard, Cztery księgi..., t. 1, ks. II, D. VI, r. 2 (27), s. 352. 
w dalszej części. Drugie to Gabriel, co się tłumaczy fortitudo Dei, czyli „Moc Boga”, i ten należy do porządku Archaniołów, które są posłańcami Bożymi. Trzecie to Rafał, co się tłumaczy medicina Dei, czyli „Lek Boga”, i jest on z porządku Aniołów, i towarzyszy synowi Tobiasza w podróży, jak czytamy w jego księdze ${ }^{\mathbf{1 2 0}}$.

Innych imion anielskich nie znamy na pewno i dlatego wszelkie inne imiona przypisywane aniołom są podejrzane i niepodparte żadnym autorytetem. I nie należy oddawać im czci, aby gdy je ktoś wzywa, nie wezwał jakiegoś złego ducha tak nazwanego i nie został nikczemnie oszukany przez owe imiona.

\section{Bibliografia}

\section{Źródła}

Biblia, to jest księgi Starego i Nowego Testamentu z łacińskiego na język polski przełożone. Dosłowny przedruk $z$ autentycznéj edycyi Krakowskiéj z r. 1599, potwierdzonéj przez Ś. Stolice Apostolską i JW księdza Arcybiskupa Gnieźnieńskiego i Poznańskiego, Bielsko-Biała 2018. Eiximenis F., Àngels e demonis, edició i comentaris de S. Martí, Barcelona 2003.

Eiximenis F., De Sant Miquel arcàngel: el quint tractat del "Libre dels àngels, introducció, edició i apèndixs de C. Wittlin, Barcelona 1983.

Eiximenis F., Dotzè del Crestià, València: Lambert Palmart, 1484.

Eiximenis F., Llibre dels àngels, Barcelona: Joan Rosenbach, 1494.

Eiximenis F., Llibre dels àngels, Barcelona: Pere Miquel, 1494.

Eiximenis F., Llibre dels àngels, XV w., Biblioteca Nacional de España, ms. 73.

Eiximenis F., Lo Crestià (selecció), a cura d’A. Hauf. Barcelona 1983.

Fizjologi i Aviarium. Średniowieczne traktaty o symbolice zwierząt, przeł. i oprac. S. Kobielus, Tyniec 2005.

Jan Damasceński, Wykład wiary prawdziwej, przeł. B. Wojkowski, Warszawa 1969.

Piotr Lombard, Cztery księgi sentencji, t. 1-2, przeł. J. Wojtkowski, Olsztyn 2013-2015.

Pismo Święte Starego i Nowego Testamentu w przekładzie z języków oryginalnych [Biblia Tysiąclecia], oprac. zespół biblistów polskich z inicjatywy benedyktynów tynieckich, wyd. 4, Poznań 2003.

Pseudo-Dionizy Areopagita, Hierarchia niebiańska, w: Pseudo-Dionizy Areopagita, Pisma teologiczne, t. 2: Hierarchia niebiańska; Hierarchia kościelna, przeł. M. Dzielska, Kraków 1999.

Strabus W., Glossa ordinaria super Genesim et Exodum, w: W. Strabus, Opera omnia, ed. J.-P. Migne, t. 2, Parisiis 1852 (Patrologiae Cursus Completus. Series Latina [PL], 113).

Tomasz z Akwinu, Suma teologiczna, t. 4: Bóg Stwórca (1. 44-49); Aniołowie (1. 50-58), przeł. i oprac. P. Bełch, London 1978.

120 Por. „I myślą oni, że Michał, Gabriel, Rafał, byli z wyższego chóru. «Michał znaczy: Któż jak Bóg; Gabriel: Moc Boga; Rafał: Lekarstwo Boga». I nie są to miana chórów, lecz duchów”, P. Lombard, Cztery księgi..., t. 1, ks. II, D. X, r. 2 (55), s. 371. 
Tomasz z Akwinu, Suma teologiczna, t. 5: Aniołowie (część druga); Świat widzialny (1. 59-64; 65-74), przeł. i oprac. P. Bełch, London 1979.

Tomasz z Akwinu, Suma teologiczna, t. 6: Człowiek. Cz. 1, 1. 75-84, przeł. i oprac. P. Bełch, London 1980.

\section{Opracowania}

Bursiewicz N., Teoria miasta idealnego Francisca Eiximenisa, „Quart” 1 (2013), nr 27, s. 3-18.

Carreras Artau T., Fray Francisco Eiximenis. Su significación religiosa, filosófico-moral, política y social, „Annals de l'Institut d'Estudis Gironins” 1 (1946), s. 270-293.

Francesc Eiximenis i la Casa Reial. Diplomatari 1373-1409, a cura de J. Riera i Sans, J. Torró i Torrent, Girona 2010.

Hauf A., D’Eiximenis a sor Isabel de Villena, Barcelona-València 1990.

Hryszko R., Sacrum w późnośredniowiecznej koncepcji miasta idealnego Francesca Eiximenisa, w: Sacrum w mieście. Średniowiecze i wczesna epoka nowożytna: wymiar religijny, kulturalny i społeczny, red. D. Quirini-Popławska, Ł. Burkiewicz, Kraków 2016, s. 39-53.

Hryszko R., Sasor R., Średniowieczne słodycze katalońskie w źródłach o literaturze (z wyborem tekstów z XIV i V wieku), Kraków 2017.

Kuksewicz Z., Zarys filozofi średniowiecznej, Warszawa 1973.

Łopat J. OFMConv, Wkład franciszkanów z XIII i XIV w. w rozwój teorii ekonomicznych (zarys problematyki), „Lignum Vitae. Rocznik teologiczny” 17 (2016), s. 89-109.

Martí S., Els ordes mendicants i la cultura, w: Història de la literatura catalana. Literatura medieval (II), Barcelona 2014, s. 13-21.

Martínez Porcell J., Introducción y traducción del De Spiritu et Anima, un opúsculo inédito atribuido a Alcher de Clairvaux, „Espíritu” 67 (2018) núm. 155, s. 11-58.

Mews C., Debating the Authority of Pseudo-Augustine's “De spiritu et anima”, „Przegląd Tomistyczny" 24 (2018), s. 321-348.

Michałowska T., Średniowieczna teoria literatury w Polsce. Rekonesans, Wrocław 2007.

Monfrin J., La Bibliothèque de Francesc Eiximenis (1409), „Studia Bibliographica” 22 (1991), s. 241-287.

Paszkowski Z., Historia idei miasta. Od antyku do renesansu, Szczecin 2015.

Rashdall H., The Universities of Europe in the Middle Ages, vol. 2, part 1, Cambridge 2010 (reprint wyd. z 1895).

Riquer A. de, Notes sobre la peculiar erudició clàssica de fra Francesc Eiximenis, „Boletín de la Real Academia de Buenas Letras de Barcelona” 43 (1991-1992), s. 51-58.

Rubió i Lluch A., Documents per l'Història de la Cultura Catalana Mig-eval, Barcelona 1908. Szewczyk J., Rozważania o domu, Białystok 2018.

Viera D.J., Uthred of Boldon, O.S.B., professor of Francesc Eiximenis, O.F.M., „Studia monastica” 45 (2003), nùm. 1, s. 53-60.

Viera D.J., Piqué J., L'estil en l'obra de Francesc Eiximenis, w: Actes del Tretzè Col-loqui Internacional de Llengua i Literatura Catalanes: Universitat de Girona, 9-12 de setembre de 2003, coord. S. Martí et al., vol. 3, Barcelona 2007, s. 437-444. 
Vila P., El viatge d’estudis de Francesc Eiximenis a París, „Quaderns de la Selva” 13 (2001), s. 265-267.

Wittlin C., Com Eiximenis tradueix i interpreta "segons que em serà vejares que sia pus profitós als lligents”. Teoria i pràctica d'una metodologia dubtos, „Estudis romànics” 38 (2016), s. 371-382.

Wittlin C., ¿És veritat que Francesc Eiximenis «inventava autors, titols de llibres, i noms de reis i d'altres persones» i que patia d’una «ingenuïtat i credulitat sense límits»?, w: Actes del Tretzè Col-loqui Internacional de Llengua i Literatura Catalanes: Universitat de Girona, 9-12 de setembre de 2003, coord. S. Martí et al., vol. 3, Barcelona 2007, s. 35-55.

Wittlin C., Francesc Eiximenis $i$ les seves fonts, „Llengua i literature” 11 (2000), s. 41-108.

Wittlin C. Referències internes en les obres de Francesc Eiximenis: indicis de quins llibres, sobre quins temes, tenia planejat l'autor, Narpan.net (2009), https://www.narpan.net/bibliotecadigital/articles/cat_view/85-wittlin-curt.html (dostęp: 2.01.2020).

\section{ROZALIA SASOR}

仓. Uniwersytet Jagielloński w Krakowie / Jagiellonian University in Kraków, Poland

(D) https://orcid.org/0000-0003-1461-8453

@ rozalia.kosmider-sasor[at]uj.edu.pl

Rozalia Sasor, PhD, Jagiellonian University, Institute of Romance Studies. Research interest: Catalan medieval literature, Catalan history, chivalric culture. Main publications: Polish translation with critical commentary of: Ramon Llull's Llibre de lorde de cavalleria (Ksiega stanu rycerskiego, 2019), Joanot Martorell's Tirant lo Blanc, 1st part (Tirant Biały, 2007); monograph (with Rafał Hryszko) Średniowieczne słodycze katalońskie w źródłach i literaturze (z wyborem tekstów z XIV i XV wieku) (2017) [Medieval Catalan Sweets in Sources and Literature (with a Selection of Texts from the 14th and 15th Century].

This research received no specific funding. 